Gazi University
Journal of Science
http://dergipark.gov.tr/gujs

\title{
Power Quality Analysis and Voltage Sag Indices Using Fuzzy Based Dual UPQC Under Unsymmetrical Fault Condition
}

\author{
Marshall Arockia Dass PHILIP (D), Peer Fathima ABDUL KAREEM* \\ School of Electrical Engineering, Vellore Institute of Technology, Chennai, India - 600127
}

\author{
Highlights \\ - Mitigate voltage sag, fault current during single line to ground fault. \\ - Analysis of real and reactive power during fault conditions. \\ - Analysis of Total Harmonics Distortion during prefault, L-G fault and post fault conditions. \\ - Analysis of Interharmonics and Subharmonics during prefault and post fault conditions. \\ - Analysis of Inrush current during starting of three phase induction motor.
}

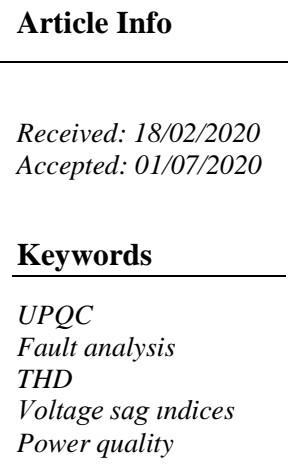

\begin{abstract}
Power quality is the major problem in the fast growing electical systems. Persistent increase in non linear loads have caused distortions in the distribution system leading to becoming unbalanced in the current and voltage waveforms which affect the quality of the power. The major power quality issues analyzed in this paper relate to voltage sag, reactive power, voltage harmonics, current harmonics, interharmonics, subharmonics, unbalanced voltage, unbalanced current, and inrush current of Induction motor.Also the line to ground fualt is created in the distribution system and analysed the power quality issues with conventional and Dual UPQC. The performance analysis of various power quality issues are compared with four different casessuch as conventional UPQC with SRF-PI controller, conventional UPQC with fuzzy controller, Dual UPQC with SRF-PI controller and Dual UPQC with fuzzy controller and the results are tabulated. The simulation results show that the performance of the fuzzy based dual UPQC controller is better than the conventional PI controller.
\end{abstract}

\section{INTRODUCTION}

Industries and customers now use converter and power electronics devices. These devices draw reactive power and harmonics, affecting the power factor and system efficiency. The term power quality is used to maintain the quality of voltage, current and frequency in generation, transmission distribution and utilization of ac electrical power.

Distortion of electric power at the consumer side is rather severe and hence it has to be analysed in the end users side. There are several reasons for the distortion of AC electric power. The first is the natural disturbance factors such as equipment failure, symmetrical and unsymmetrical faults, lightning, and flash over. The second relates to customer equipment act as non linear loads. Around 60\% of AC power supply pollution occurs due to nature causes and $40 \%$ occurs due to non-linear loads. Therefore deviation in voltage, current and frequency may lead to failure of customer equipment. Various non-linear loads connected at the point of common coupling may lead to different power quality issues, and voltage related problems such as voltage sag, voltage swell, voltage imbalance, fluctuations, glitches, flicker, outages, voltage harmonics etc. Some of the current related problems are current harmonics, current imbalance, reactive power burden, poor power factor, and excessive neutral current in polyphase system. 
To overcome this power quality problems, utility must ensure good quality of power to the consumer to enable proper application of the equipment and the manufacturer must design an electric equipment that withstands disturbance.There are various benchmarks created by Institute of Electrical and Electronics Engineers (IEEE) and International Electro technical commission(IEC), to eliminate power quality problems in utilities, customers and manufacturers. Dynamic voltage restorer (DVR), Distribution static synchronous compensator (DSTATCOM) and unified power quality conditioners (UPQC) are the power quality devices that help eliminating voltage related problems, current related problems and combination of both [1].

Voltage sag mostly occurs in the system due to unsymmetrical fault and UPQC is the only device activate very fast and does not allow any disturbance in the distribution system [2]. During symmetrical fault in the wind turbine generator, UPQC supply power to the grid and maintain the grid code requirement [3].Various faults such as single line to ground fault, double line to ground fault and three phase to ground fault are created in the distribution system and compensated using synchronous reference frame theory (SRF) based UPQC and Artificial Neural network based UPQC [4]. Voltage interruption is also eliminated using UPQC in distribution systems [5]. In the field of power electronics and power system, recent research proclaim that artificial intelligence based controllers are potential [6,7]. To extract the reference current and reference voltage for shunt and series active filter conventional Proportional integral(PI) controller is replaced with fuzzy controller [8,9]. In reference [10], it is mentioned that the conventional UPQC has some demerits like complex harmonic extraction of the grid voltage and the load involving complex calculations, voltage and current references with harmonic contents requiring a high bandwidth control, and the leakage inductance of the series connection transformer affecting the voltage compensation generated by the series filter.

To rectify the problems in UPQC, this paper addresses the new custom power device fuzzy based Dual UPQC for mitigating the various power quality issues under unsymmetrical line to ground fault condition.

\section{UPQC AND DUAL UPQC WITH CONTROL CIRCUIT}

Figures 1 and 2 shows the three phase system with conventional and Dual UPQC. In Conventional UPQC, series active filter acts as a voltage controller and shunt active filter acts as a current controller. Series active filter and shunt active filter compensate the voltage and current related problems.

In Dual UPQC, series active filter acts as a current controller, while the shunt active filter acts as a voltage controller. Series active filter and shunt active filter solves the current and voltage related problems [10$16]$.

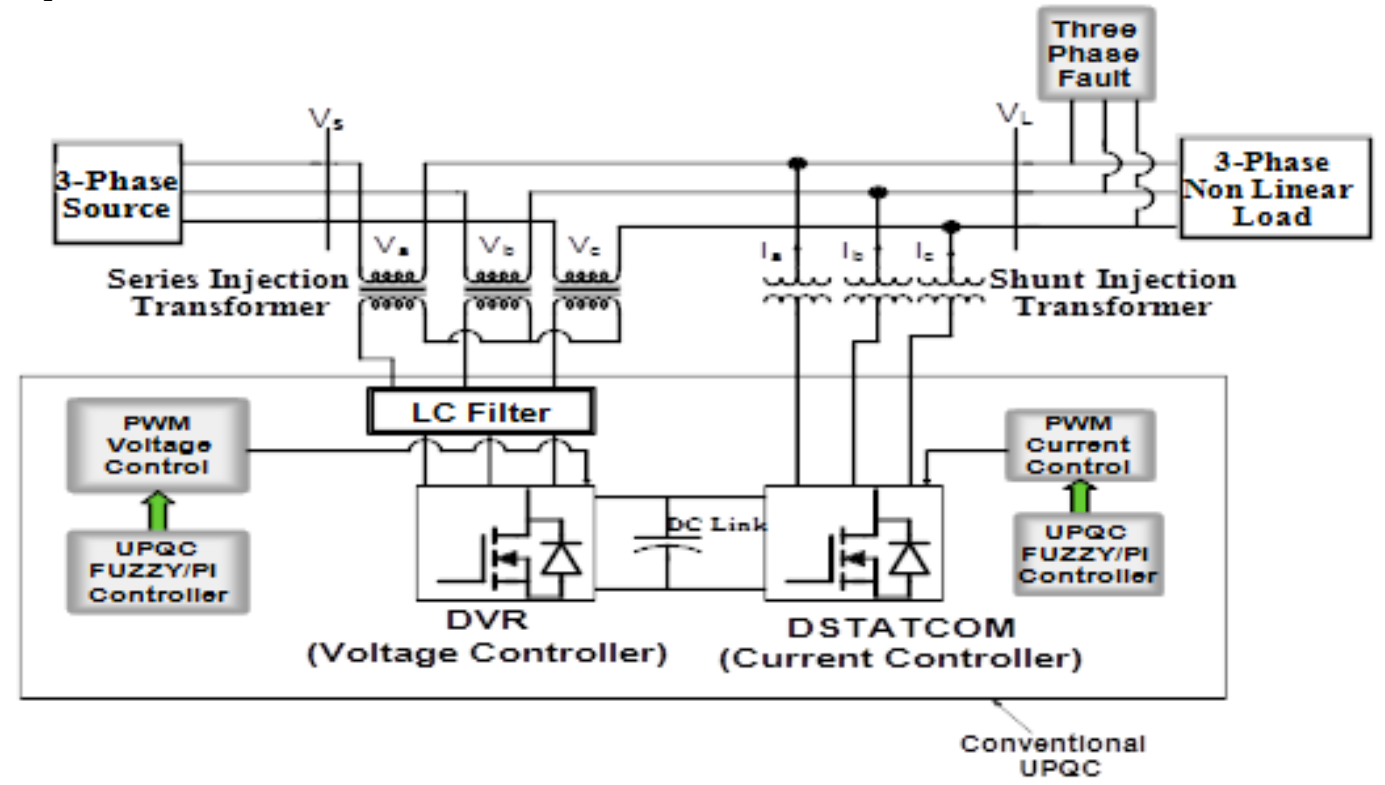

Figure 1. Schematic diagram of three phase system with Conventional UPQC 


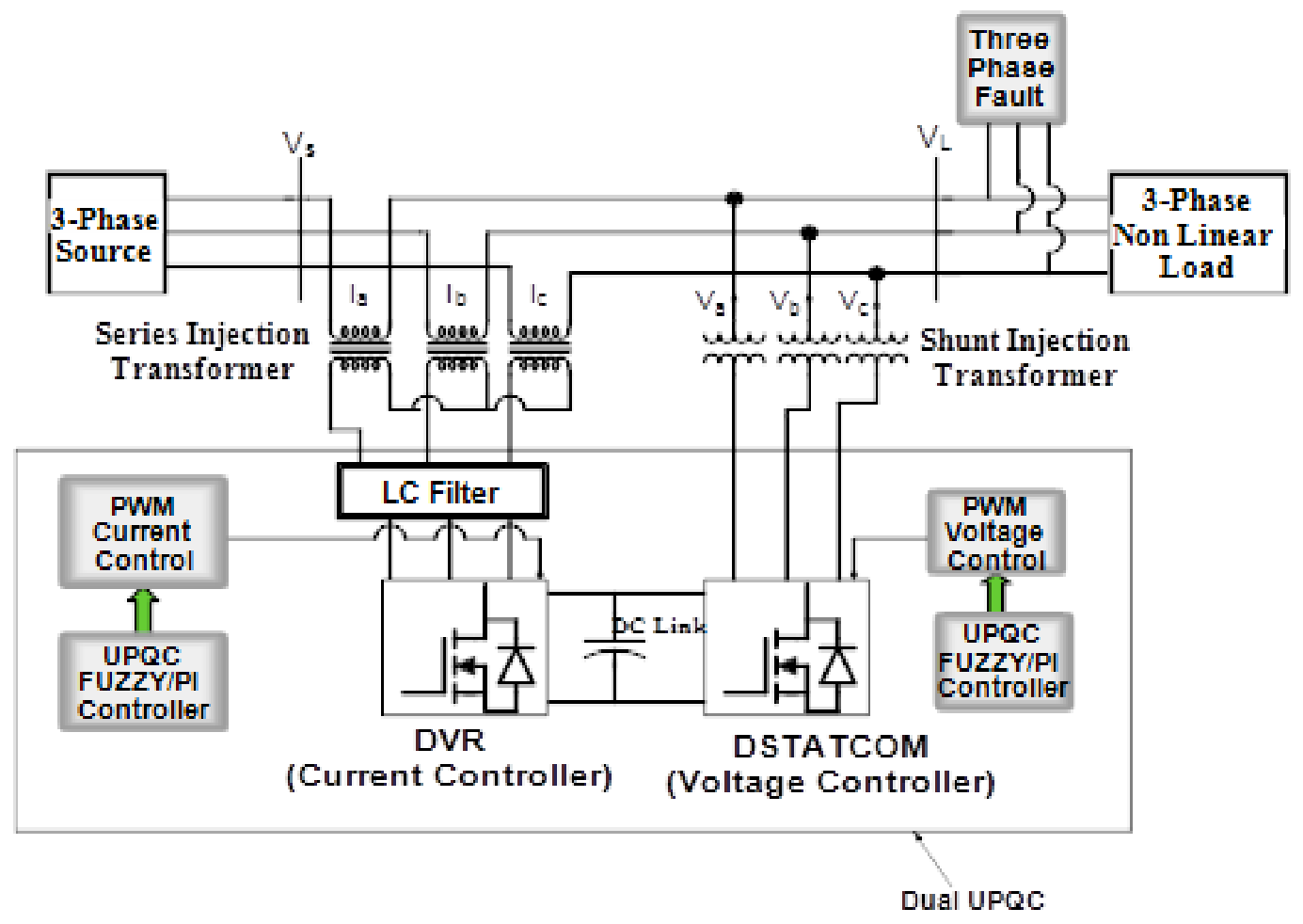

Figure 2. Schematic diagram of three phase system with Dual UPQC

Two control techniques namely SRF based PI control algorithm and fuzzy based control algorithm are implemented to control the PWM voltage / current in conventional and Dual UPQC which is described in section 2.1 and 2.2. Design of DSTATCOM is explained in section 2.3.

\subsection{SRF Based Control Algorithm with PI Controller for Dual UPQC}

In the Conventional UPQC control circuit, voltage error signal is given as input for Dynamic voltage restorer, whereas current error signal is given as input for DSTATCOM. In the Dual UPQC control circuit, current error signal is given as input for Dynamic voltage restorer, whereas voltage error signal is given as input for DSTATCOM. The working of DVR and DSTATCOM using the synchronous reference frame theory and the control circuit of series part of Dual UPQC explained in [16] is adopted here.

Figure 3 presents the SRF based control circuit for DVR in Dual UPQC. In this circuit DC bus Voltage $\left(\mathrm{V}_{\mathrm{DC}}\right)$, PCC Voltage $\left(\mathrm{V}_{\mathrm{sa}}, \mathrm{V}_{\mathrm{sb}}, \mathrm{V}_{\mathrm{sc}}\right)$ actual current $\left(\mathrm{i}_{\mathrm{La}}, \mathrm{i}_{\mathrm{Lb}}, \mathrm{i}_{\mathrm{Lc}}\right)$ are sensed from the Electric power distribution system as feedback signals. The three phase load currents are transformed into dq0 frame using park's transformation as follows

$\left[\begin{array}{c}\mathrm{I}_{\mathrm{Ld}} \\ \mathrm{I}_{\mathrm{Lq}} \\ \mathrm{I}_{\mathrm{L} 0}\end{array}\right]=\frac{2}{3}\left[\begin{array}{ccc}\cos \theta & -\sin \theta & \frac{1}{2} \\ \cos \left(\theta-\frac{2 \pi}{3}\right) & -\sin \left(\theta-\frac{2 \pi}{3}\right) & \frac{1}{2} \\ \cos \left(\theta+\frac{2 \pi}{3}\right) & \sin \left(\theta+\frac{2 \pi}{3}\right) & \frac{1}{2}\end{array}\right]\left[\begin{array}{l}\mathrm{I}_{\mathrm{La}} \\ \mathrm{I}_{\mathrm{Lb}} \\ \mathrm{I}_{\mathrm{Lc}}\end{array}\right]$ 
A 3Ф Phase locked loop(PLL) is used for synchronizing PCC voltage with these signals. These dq0 current components $i_{L d}, i_{L q}$ are passed through low pass filter (LPF) to extract the DC components $i_{d D C}$ and $i_{q D C}$. The direct axis and quadrature axis current consist of DC and AC components.

$$
\begin{aligned}
& \dot{\mathbf{i}}_{\mathrm{Ld}}=\mathbf{i}_{\mathrm{dDC}}+\mathbf{i}_{\mathrm{dAC}} \\
& \mathbf{i}_{\mathrm{Lq}}=\mathbf{i}_{\mathrm{qDC}}+\mathbf{i}_{\mathrm{qAC}} .
\end{aligned}
$$

SRF controller generates DC quantities by LPF and hence the AC quantities are separated from the reference signals. It can work in ZVR and UPF modes.

Figure 4 shows the SRF-PI based control algorithm for DSTATCOM in Dual UPQC

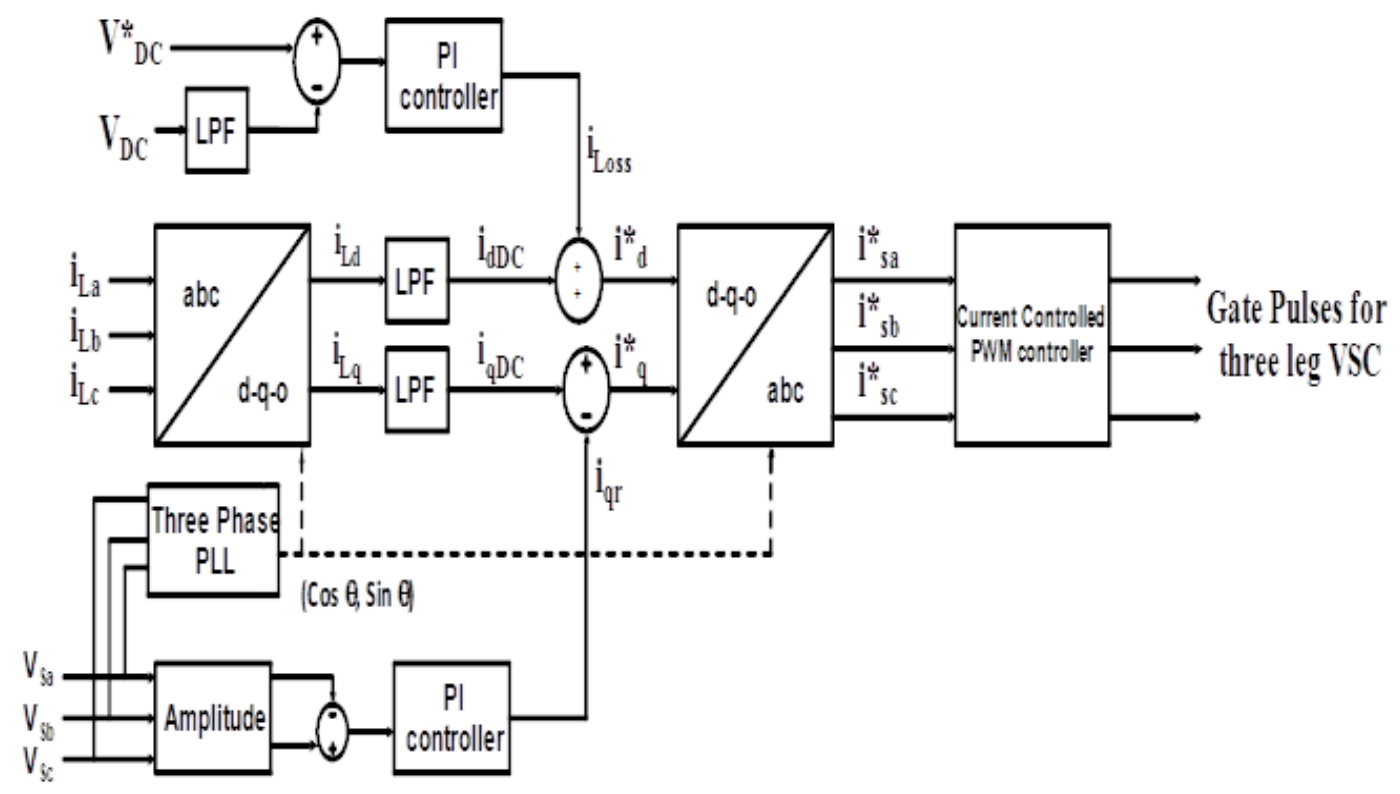

Figure 3. Block diagram of SRF theory-based control algorithm of DVR in Dual UPQC

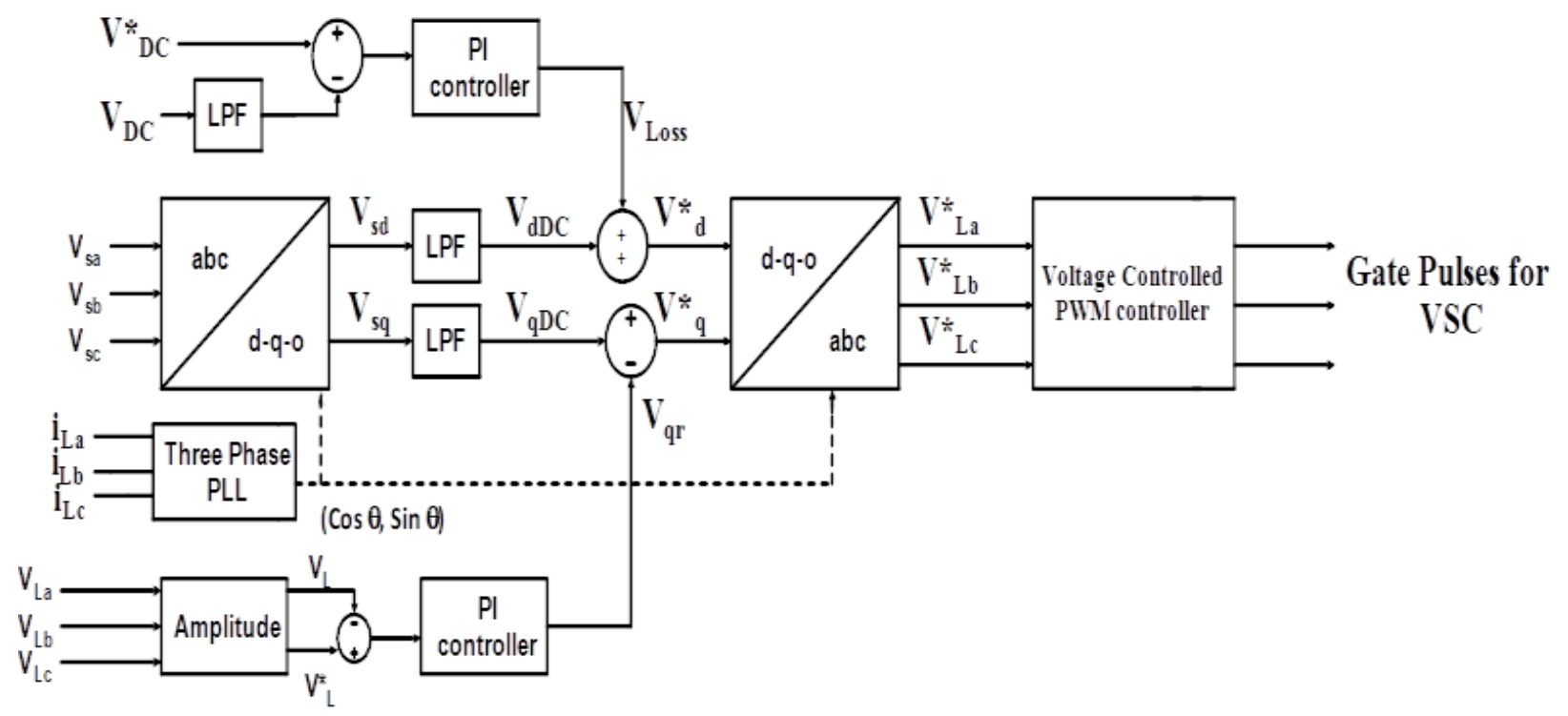

Figure 4. Block diagram of SRF theory-based control algorithm of DSTATCOM in Dual UPQC 


\subsection{Fuzzy based Control Algorithm for Dual UPQC}

Figure 5 shows the Fuzzy based control circuit for DVR portion of Dual UPQC. In this circuit, actual DC voltage is compared with reference DC voltage and the error voltage and change in error voltage is given as input to Fuzzy Controller.

The linguistic variables are used in the Fuzzy logic controller instead of numerical variables. Fuzzy controller can be classified into three steps namely, Fuzzification, Inference and Defuzzification. In Fuzzification, numerical values are converted into linguistic variable. Triangular membership function is used with seven linguistic variables. Fuzzy rule shown in Table 1 is adopted here [17]. In Defuzzification stage linguistic variable are converted in to numerical values. Centroid method is used for Defuzzification.

The output of the fuzzy controller is given to the multiplier through limiter, the reference source current is obtained from unit amplitude generation through multiplier. The unit amplitude generation is obtained by phase locked loop. The reference source current is compared with the load current gives compensation reference current. In hysteresis current controller, compensation reference current is compared with reference currrent the output is injected by the compensation circuit.

Figure 6 presents the Fuzzy based control circuit for DSTATCOM portion of Dual UPQC. In this circuit Actual DC voltage is compared with reference DC voltage, the error voltage and change in error voltage is given input to Fuzzy Controller. The output of the fuzzy controller is given to the multiplier through limiter, the reference source voltage is obtained from unit amplitude generation through multiplier. The unit amplitude generation is obtained by phase locked loop. The reference source voltage is compared with the load voltage gives compensation reference voltage. In hysteresis voltage controller, compensation reference voltage is compared with reference voltage the output is injected by the compensation circuit.

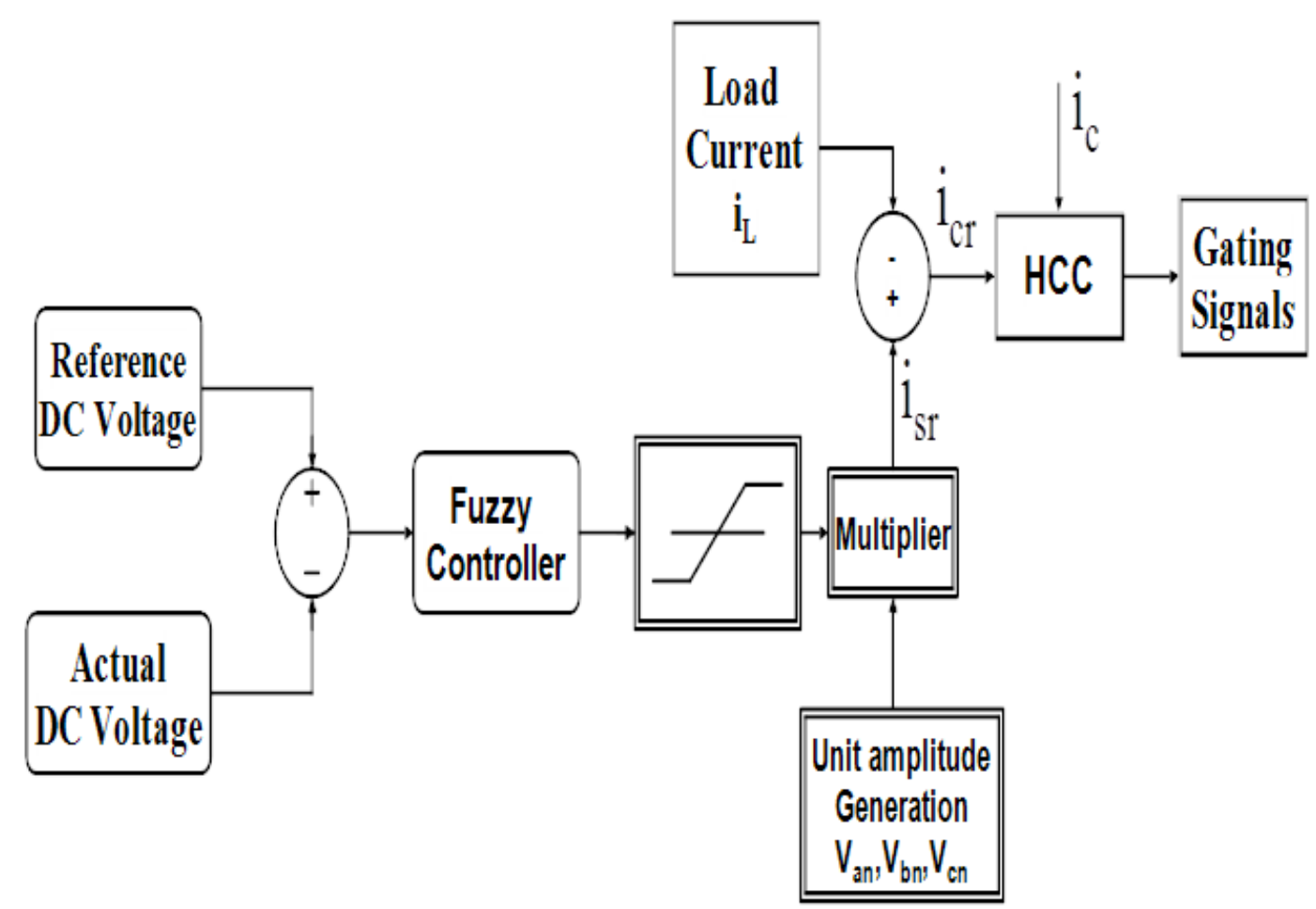

Figure 5. Fuzzy based control circuit for DVR portion of Dual UPQC 


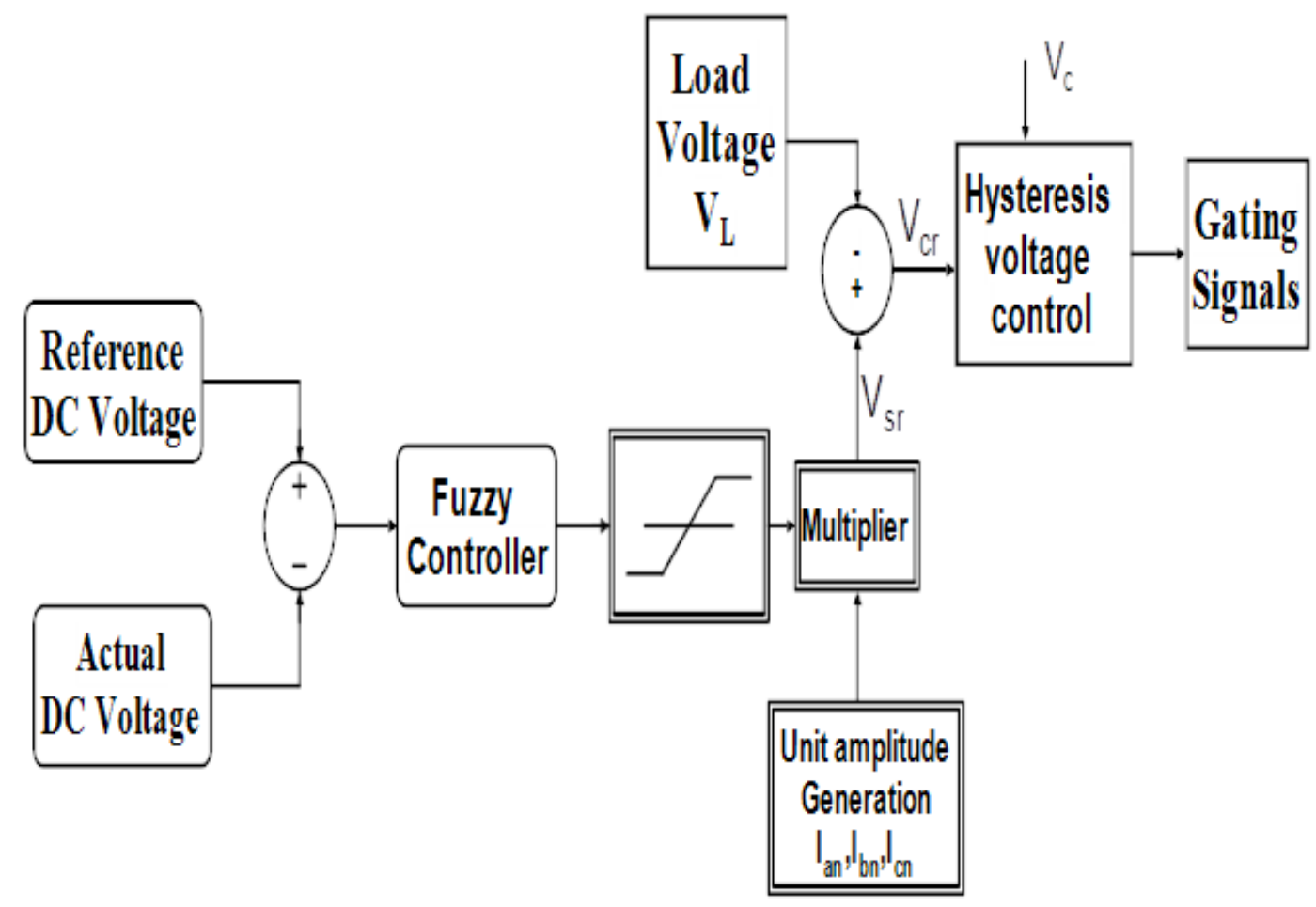

Figure 6. Fuzzy based control circuit for DSTATCOM portion of Dual UPQC

Table 1. Fuzzy Rule Table

\begin{tabular}{|c|c|c|c|c|c|c|c|c|}
\hline \multicolumn{9}{|c|}{ Error (e) } \\
\hline \multirow{8}{*}{$\begin{array}{l}\text { Change } \\
\text { in error } \\
\text { (ce) }\end{array}$} & & NB & NM & NS & $\mathrm{ZE}$ & PS & PM & PB \\
\hline & NB & NB & NB & NB & NB & NM & NS & ZE \\
\hline & NM & NB & NB & NB & NM & NS & $\mathrm{ZE}$ & PS \\
\hline & NS & NB & NB & NM & NS & $\mathrm{ZE}$ & PS & PM \\
\hline & $\overline{Z E}$ & NB & NM & NS & $\overline{Z E}$ & PS & PM & PB \\
\hline & PS & NM & NS & $\mathrm{ZE}$ & PS & PM & PB & PB \\
\hline & $\mathrm{PM}$ & NS & ZE & PS & PM & PB & PB & PB \\
\hline & PB & $\mathrm{ZE}$ & PS & PM & PB & PB & PB & PB \\
\hline
\end{tabular}

\subsection{Design of DSTATCOM portion of Dual UPQC}

Selection of DC Bus Voltage

$\mathrm{V}_{\mathrm{DC}}=\frac{2 \sqrt{2} \mathrm{~V}_{\mathrm{LL}}}{\sqrt{3} \mathrm{~m}}$

m- Modulation index

$\mathrm{V}_{\mathrm{LL}}=$ Line to line voltage.

Selection of DC bus capacitor

$\frac{1}{2} \mathrm{C}_{\mathrm{DC}}\left[\mathrm{V}_{\mathrm{DC}}^{2}-\mathrm{V}_{\mathrm{DC} 1}^{2}\right]=\mathrm{k}_{1} 3$ VaIt

$\mathrm{V}_{\mathrm{DC}}-$ Reference $\mathrm{DC}$ voltage

$\mathrm{V}_{\mathrm{DC} 1}-$ Actual DC voltage

a - Overloading factor

$\mathrm{k}_{1}-$ Variation of energy during dynamics. 


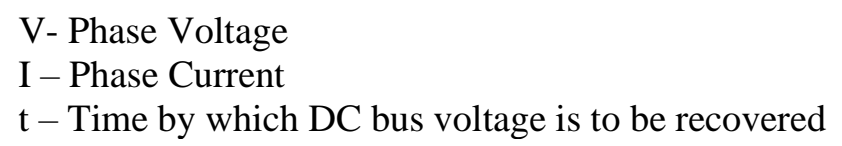

Table 2. Parameters of the three phase system and UPQC

\begin{tabular}{|l|l|}
\hline Parameter & Value \\
\hline Supply Voltage (Peak to Peak) & $415 \mathrm{~V}$ \\
\hline Frequency & $50 \mathrm{~Hz}$ \\
\hline Line resistance & $0.632 \Omega$ \\
\hline Line Inductance & $4 \mathrm{mH}$ \\
\hline Injection transformer turns ratio & $1: 1$ \\
\hline Series Injection transformer & $25 \mathrm{KVA}$ \\
\hline Shunt Injection transformer & $80 \mathrm{KVA}$ \\
\hline Switching Frequency & $1 \mathrm{kHz}$ \\
\hline Load Real Power & $20 \mathrm{KW}$ \\
\hline Load Inductive Reactive Power & $100 \mathrm{VAR}$ \\
\hline Filter inductance & $1 \mathrm{mH}$ \\
\hline Filter capacitance & $10 \mu \mathrm{F}$ \\
\hline DC link capacitor & $5 \mathrm{mF}$ \\
\hline DC bus voltage & $700 \mathrm{~V}$ \\
\hline
\end{tabular}

\section{SIMULATION RESULTS AND DISCUSSION}

A three phase system shown in Figures 1 and 2 are used to analyze the performance of UPQC and dual UPQC with two different algorithmsand the parameters are shown in Table 2 . To analyse the power quality issues, line to ground (L-G) fault is created after bus 2 in Figure 1, between 0.2 to 0.3 seconds. Voltage sag, interruption, fault current, real power and reactive power are manifested in Figure 1 and Figure 7. The results are compared with four different cases namely, the conventional UPQC with PI controller, Conventional UPQC with Fuzzy Controller, Dual UPQC with PI controller, and Dual UPQC with Fuzzy Controller.

From Table 3 and Figures 7a and 8a, it is observed that, voltage at Bus 1 is started reducing from 406V and reaches the switching transient value $386.7 \mathrm{~V}$ under prefault condition. The dip value $387.3 \mathrm{~V}$ is maintained upto 0.3 seconds, after that it reaches 406V at 0.32 seconds. Similarly in Bus 2, the voltage starts reducing from $338.6 \mathrm{~V}$ and reaches the switching transient value $232 \mathrm{~V}$. The dip value of $235 \mathrm{~V}$ is maintained upto 0.3 seconds and starts increasing and reaches $338.6 \mathrm{~V}$ at 0.32 seconds. The performance of UPQC with four different controllers operated under single line to ground fault at bus 1 voltage is analysed for the time duration of 0 to 0.5 seconds. For the conventional UPQC with PI controller the voltage gradually increases from $406.5 \mathrm{~V}$ at 0.02 seconds and $408.5 \mathrm{~V}$ at 2.5 seconds. For the Dual UPQC with PI controller the voltage gradually increases from $408 \mathrm{~V}$ at 0.02 seconds and $409 \mathrm{~V}$ at 2.5 seconds. The Conventional and Dual UPQC with Fuzzy controller maintains the voltage at $409.2 \mathrm{~V}$ at 0.02 seconds for the entire duration. Table 3 and Figure $7 \mathrm{~b}$ and $8 \mathrm{~b}$ shows the prefault conditions current related issues at Bus 1 and Bus 2 for linear and non linear load. The current 44A in Linear Load increases to 67A in non linear load due to current harmonics. During L-G fault, the current $44 \mathrm{~A}$ is increased to $100.5 \mathrm{~A}$ for linear load and $67 \mathrm{~A}$ is increased to $114 \mathrm{~A}$ for non linear load. For transient case the non linear load reaches the current value of 125.6A. After insertion of UPQC with different controllers, the current in Bus 1 and Bus 2 is maintained at 44A during unsymmetrical L-G fault condition.

Table 3 and Figures 7c, 8c, 7d and 8d shows the values of real and reactive power of Bus 1 and Bus2 under linear and non linear load conditions. It is observed that Bus 1 and Bus2 real and reactive power is increased due to harmonics under prefault conditions. During L-G fault at Bus 1, the real power is increased from $37.3 \mathrm{KW}$ to $53.8 \mathrm{KW}$ and reactive power is increased from 16.5KVAR to $55 \mathrm{KVAR}$ due to power oscillations. Similarly it is observed in other two cases. After insertion of UPQC with four different controllers, the real and reactive power oscillations are reduced and maintained to nearest prefault values. 
Tables 4 to 6 and Figures 9 and 10 shows the result analysis of THD distribution system under prefault, during fault and post fault conditions. The Voltage and current THD results are compared for different control strategies such as without UPQC, conventional UPQC-PI, conventional UPQC-Fuzzy, Dual UPQCPI, and Dual UPQC-Fuzzy. During prefault, THD is measured at 0.05 seconds and during fault conditions THD is measured at 0.25 seconds. From Table 5 row 1 , it is observed that PI based conventional (0.03) and Fuzzy based conventional UPQC and Dual UPQC (0.05) gives better THD results than PI based Dual UPQC(1.87). From Table 6 after clearing the L-G fault, THD is measured at 0.35 seconds, PI based conventional UPQC (0.11) gives better THD results than Fuzzy controller(0.23). Eventhough the values for fuzzy based dual UPQC values are slightly higher than the PI based dual UPQC, the values of voltage and current THD are within $8 \%$ of permissible limit and met with the IEEE standard 519-2014[18].

Voltage interharmonics are measured during prefault condition at Bus 1 and Bus 2 in two bus distribution system. The results are compared for different control strategies such as without UPQC, conventional UPQC-PI, conventional UPQC-Fuzzy, Dual UPQC-PI, and Dual UPQC-Fuzzy. It is observed from Table 7 and 8, first row R phase, Fuzzy based Dual UPQC is maintained the interharmonics source and load voltage as $0.01 \%$ and $0.06 \%$ for frequency $75 \mathrm{~Hz}$. Also it is observed that the values are met with IEC standard [19-23].

The sources of subharmonics present in distribution systems include Induction motor, transformer, Lightning systems, cycloconverter fed system [24] and capacitor connected in series. During faults or switching events, the subharmonic currents are amplified [25] and it is measured below $50 \mathrm{~Hz}$ as per IEC standard.

Table 9 shows the analysis of the voltage and current subharmonics measured during prefault condition at Bus 1 and Bus 2. The results are compared without UPQC, conventional UPQC-PI, conventional UPQCFuzzy, Dual UPQC-PI, and Dual UPQC-Fuzzy. From the results it is observed that source voltage of Fuzzy based Dual UPQC system having less subharmonics in all the three phases $(0,0.01,0.01)$ compared to PI based dual UPQC $(0.07,0.01,0.08)$ system. The subharmonics present in the source current, load voltage and load current are also very less in Fuzzy based Dual UPQC distribution system.

Sag score is calculated using the formula mentioned in the references [26-30]. Figure 11 shows the analysis of Sag Score under L-G fault condition. It is observed that sag score at bus1 and 2 for fuzzy based dual UPQC is lesser than the other controllers. Also it is observed from the results, the voltage profile is properly maintained.

Table 10 and Figures 12 to 14 represents the various system parameters of 5.4HP Induction motor at the time of starting. In case of without UPQC, the starting current 80 A exists between 0.0 to 0.05 seconds and then it is reduced to $9.6 \mathrm{~A}$ which is unbalanced for the entire duration. Generator Bus voltage varies from $400 \mathrm{~V}$ to $405 \mathrm{~V}$ and Load Bus voltage varies from 310 to $380 \mathrm{~V}$ between 0.0 to 0.05 seconds. After $50 \mathrm{~ms}$, Generator bus voltage $(409 \mathrm{~V}-413 \mathrm{~V})$ and load bus voltage $(395 \mathrm{~V}-405 \mathrm{~V})$ are unbalanced for the entire duration. After the insertion of conventional UPQC - Fuzzy, the starting current at 50ms is 12A and it is reduced to rated current 9.6A for the entire duration, producing balanced sinusoidal current. Also the balanced Generator Bus voltage of $414 \mathrm{~V}$ and load bus voltage of $404 \mathrm{~V}$ are maintained for the entire duration. The Dual UPQC Fuzzy also provides the same result, with less voltage and current fluctuations compared with the conventional UPQC-Fuzzy. The main advantages of reducing the starting current of three phase induction motor with fuzzy based Dual UPQC are system reliability, easy drive and control system, less voltage drop in the power supply network, and Direct Starting.

Based on the entire results, it is proved that the performance of Fuzzy based Dual UPQC is better than the other controllers in three phase distribution systems. 
Table 3. Performance analysis of various Distribution System parameters during prefault and Line to Ground Fault

\begin{tabular}{|c|c|c|c|c|c|c|c|c|c|c|c|c|c|}
\hline \multirow{4}{*}{$\begin{array}{l}\text { System } \\
\text { Parameters }\end{array}$} & \multirow{3}{*}{\multicolumn{2}{|c|}{ Pre-fault }} & \multicolumn{11}{|l|}{ L-G } \\
\hline & & & \multicolumn{3}{|c|}{ Without UPQC } & \multirow{2}{*}{\multicolumn{2}{|c|}{$\begin{array}{l}\text { PI based } \\
\text { conventional } \\
\text { UPQC }\end{array}$}} & \multirow{2}{*}{\multicolumn{2}{|c|}{$\begin{array}{l}\text { FUZZY } \\
\text { based } \\
\text { conventional } \\
\text { UPQC }\end{array}$}} & \multirow{2}{*}{\multicolumn{2}{|c|}{$\begin{array}{l}\text { PI based } \\
\text { Dual UPQC }\end{array}$}} & \multirow{2}{*}{\multicolumn{2}{|c|}{$\begin{array}{l}\text { FUZZY } \\
\text { based Dual } \\
\text { UPQC }\end{array}$}} \\
\hline & & & \multicolumn{2}{|c|}{$\begin{array}{l}\text { Non Linear } \\
\text { Load }\end{array}$} & \multirow{2}{*}{ 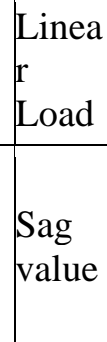 } & & & & & & & & \\
\hline & $\mid \begin{array}{l}\text { Non } \\
\text { Linear } \\
\text { Load }\end{array}$ & $\begin{array}{l}\text { Linea } \\
r \\
\text { Load }\end{array}$ & $\begin{array}{l}\text { Switchin } \\
\mathrm{g} \\
\text { transient }\end{array}$ & \begin{tabular}{|l} 
Sag \\
Value
\end{tabular} & & $\begin{array}{l}\text { Linea } \\
\mathrm{r} \\
\text { Load }\end{array}$ & $\begin{array}{l}\text { Non } \\
\text { Linea } \\
r \\
\text { Load }\end{array}$ & $\begin{array}{l}\text { Linear } \\
\text { Load }\end{array}$ & $\begin{array}{l}\text { Non } \\
\text { Linea } \\
\mathrm{r} \\
\text { Load }\end{array}$ & $\begin{array}{l}\text { Linear } \\
\text { Load }\end{array}$ & $\begin{array}{l}\text { Non } \\
\text { Linea } \\
\text { r } \\
\text { Load }\end{array}$ & $\begin{array}{l}\text { Linear } \\
\text { Load }\end{array}$ & $\begin{array}{l}\text { Non } \\
\text { Linea } \\
\text { r } \\
\text { Load }\end{array}$ \\
\hline \begin{tabular}{l|l} 
Bu & $\begin{array}{l}\text { Voltage } \\
\text { (Volts) }\end{array}$
\end{tabular} & 406 & 413 & 386.7 & $\begin{array}{l}387.3 \\
3\end{array}$ & 390 & 409 & 409 & $\begin{array}{l}411.3 \\
1\end{array}$ & 409.2 & $\begin{array}{l}410.6 \\
2\end{array}$ & 408 & $\begin{array}{l}411.3 \\
1\end{array}$ & 409.2 \\
\hline $\begin{array}{l}\text { Current } \\
\text { (Amps) }\end{array}$ & 67 & 44 & 125.6 & 114 & 100.5 & 44 & 44.4 & 32.15 & 43.95 & 34.6 & 44 & 32.1 & 43.95 \\
\hline $\begin{array}{ll} & \text { Voltage } \\
\mathrm{Bu} & \text { (Volts) }\end{array}$ & 338.6 & 380 & 232 & 235.3 & 254 & 362 & 362.6 & 379.1 & 363.1 & $\begin{array}{l}374.7 \\
4\end{array}$ & 360 & 379.2 & 363.3 \\
\hline $\begin{array}{l}\text { Current } \\
\text { (Amps) }\end{array}$ & 67 & 44 & 125.6 & 114 & 100.5 & 44 & 44.4 & 32.15 & 43.95 & 34.6 & 44 & 32.1 & 43.95 \\
\hline $\begin{array}{l}\text { Real } \\
\text { Power } \\
(\mathrm{KW})\end{array}$ & 37.3 & 27 & 53.8 & 43 & 37.1 & 24 & 24.8 & 18.54 & 24.5 & 19.65 & 24 & 18.52 & 24.6 \\
\hline $\begin{array}{ll}\text { s } 1 & \text { Reactiv } \\
& \text { e Power } \\
& \text { (KVAR }\end{array}$ & 16.5 & 3.815 & 55 & 50 & 45.55 & 11 & 11.25 & 7.05 & 11.15 & 8.35 & 12.4 & 7.04 & 11.1 \\
\hline $\begin{array}{l}\text { Real } \\
\text { Power } \\
(\mathrm{KW})\end{array}$ & 33.05 & 25 & 41.6 & 30.9 & 27.56 & 22 & 22.9 & 17.56 & 22.7 & 18.51 & 22.2 & 17.54 & 22.7 \\
\hline \begin{tabular}{l|l} 
s 2 & $\begin{array}{l}\text { Reactiv } \\
\text { e Power } \\
\\
\end{array}$ \\
& (KVAR
\end{tabular} & 8.05 & 0.126 & 28.8 & 25.65 & 26.5 & 7.484 & 7.520 & 5.105 & 7.532 & 6.08 & 8.55 & 5.09 & 7.460 \\
\hline
\end{tabular}

Table 4. Performance Analysis of THD in Distribution System at Bus1 and Bus2 - Prefault

\begin{tabular}{|l|l|l|l|l|l|}
\hline$\%$ THD & $\begin{array}{l}\text { Without } \\
\text { UPQC }\end{array}$ & $\begin{array}{l}\text { PI based } \\
\text { conventional } \\
\text { UPQC }\end{array}$ & $\begin{array}{l}\text { FUZZY based } \\
\text { conventional } \\
\text { UPQC }\end{array}$ & $\begin{array}{l}\text { PI based Dual } \\
\text { UPQC }\end{array}$ & $\begin{array}{l}\text { FUZZY based } \\
\text { Dual UPQC }\end{array}$ \\
\hline $\mathrm{V}_{\mathrm{THD}}(\mathrm{R} 1)$ & 4.29 & 0.21 & 0.05 & 0.69 & 0.05 \\
\hline $\mathrm{V}_{\mathrm{THD}}(\mathrm{Y} 1)$ & 4.29 & 0.23 & 0.05 & 0.75 & 0.05 \\
\hline $\mathrm{V}_{\mathrm{THD}}(\mathrm{B} 1)$ & 4.30 & 0.26 & 0.05 & 0.55 & 0.05 \\
\hline $\mathrm{I}_{\mathrm{THD}}(\mathrm{R} 1)$ & 14.65 & 1.62 & 0.23 & 6.63 & 0.22 \\
\hline $\mathrm{I}_{\mathrm{THD}}(\mathrm{Y} 1)$ & 14.66 & 2.00 & 0.23 & 6.85 & 0.22 \\
\hline $\mathrm{I}_{\mathrm{THD}}(\mathrm{B} 1)$ & 14.66 & 2.23 & 0.23 & 4.53 & 0.22 \\
\hline $\mathrm{V}_{\mathrm{THD}}(\mathrm{R} 2)$ & 25.79 & 1.19 & 0.30 & 3.98 & 0.28 \\
\hline $\mathrm{V}_{\mathrm{THD}}(\mathrm{Y} 2)$ & 25.81 & 1.33 & 0.30 & 4.27 & 0.28 \\
\hline $\mathrm{V}_{\mathrm{THD}}(\mathrm{B} 2)$ & 25.83 & 1.46 & 0.30 & 3.13 & 0.28 \\
\hline $\mathrm{I}_{\mathrm{THD}}(\mathrm{R} 2)$ & 14.65 & 1.62 & 0.23 & 6.63 & 0.22 \\
\hline
\end{tabular}




\begin{tabular}{|l|l|l|l|l|l|}
\hline $\mathrm{I}_{\mathrm{THD}}(\mathrm{Y} 2)$ & 14.66 & 2.00 & 0.23 & 6.85 & 0.22 \\
\hline $\mathrm{I}_{\mathrm{THD}}(\mathrm{B} 2)$ & 14.66 & 2.23 & 0.23 & 4.53 & 0.22 \\
\hline
\end{tabular}

Table 5. Performance Analysis of THD in Distribution System at Bus1 and Bus2 during Line to Ground Fault

\begin{tabular}{|l|l|l|l|l|l|}
\hline$\%$ THD & $\begin{array}{l}\text { Without } \\
\text { UPQC }\end{array}$ & $\begin{array}{l}\text { PI based } \\
\text { conventional } \\
\text { UPQC }\end{array}$ & $\begin{array}{l}\text { FUZZY } \\
\text { based } \\
\text { conventional } \\
\text { UPQC }\end{array}$ & $\begin{array}{l}\text { PI based Dual } \\
\text { UPQC }\end{array}$ & $\begin{array}{l}\text { FUZZY } \\
\text { based Dual } \\
\text { UPQC }\end{array}$ \\
\hline $\mathrm{V}_{\mathrm{THD}}(\mathrm{R} 1)$ & 0.00 & 0.03 & 0.05 & 1.87 & 0.05 \\
\hline $\mathrm{V}_{\mathrm{THD}}(\mathrm{Y} 1)$ & 2.41 & 0.03 & 0.05 & 1.95 & 0.05 \\
\hline $\mathrm{V}_{\mathrm{THD}}(\mathrm{B} 1)$ & 2.53 & 0.03 & 0.05 & 2.00 & 0.05 \\
\hline $\mathrm{I}_{\mathrm{THD}}(\mathrm{R} 1)$ & 0.03 & 0.25 & 0.24 & 2.91 & 0.22 \\
\hline $\mathrm{I}_{\mathrm{THD}}(\mathrm{Y} 1)$ & 10.58 & 0.22 & 0.23 & 3.24 & 0.22 \\
\hline $\mathrm{I}_{\mathrm{THD}}(\mathrm{B} 1)$ & 10.06 & 0.22 & 0.23 & 3.29 & 0.23 \\
\hline $\mathrm{V}_{\mathrm{THD}}(\mathrm{R} 2)$ & 5.09 & 0.16 & 0.31 & 1.87 & 0.28 \\
\hline $\mathrm{V}_{\mathrm{THD}}(\mathrm{Y} 2)$ & 12.84 & 0.15 & 0.30 & 1.95 & 0.28 \\
\hline $\mathrm{V}_{\mathrm{THD}}(\mathrm{B} 2)$ & 16.15 & 0.16 & 0.30 & 2.00 & 0.29 \\
\hline $\mathrm{I}_{\mathrm{THD}}(\mathrm{R} 2)$ & 0.03 & 0.25 & 0.24 & 2.91 & 0.22 \\
\hline $\mathrm{I}_{\mathrm{THD}}(\mathrm{Y} 2)$ & 10.58 & 0.22 & 0.23 & 3.24 & 0.22 \\
\hline $\mathrm{I}_{\mathrm{THD}}(\mathrm{B} 2)$ & 10.06 & 0.22 & 0.23 & 3.29 & 0.23 \\
\hline
\end{tabular}

Table 6. THD Analysis in Distribution System after Clearing Line to Ground Fault

\begin{tabular}{|l|l|l|l|l|l|}
\hline$\%$ THD & $\begin{array}{l}\text { Without } \\
\text { UPQC }\end{array}$ & $\begin{array}{l}\text { PI based } \\
\text { conventional } \\
\text { UPQC }\end{array}$ & $\begin{array}{l}\text { FUZZY based } \\
\text { conventional } \\
\text { UPQC }\end{array}$ & $\begin{array}{l}\text { PI based Dual } \\
\text { UPQC }\end{array}$ & $\begin{array}{l}\text { FUZZY based } \\
\text { Dual UPQC }\end{array}$ \\
\hline $\mathrm{V}_{\mathrm{THD}}(\mathrm{R} 1)$ & 10.74 & 0.11 & 0.26 & 0.25 & 0.23 \\
\hline $\mathrm{V}_{\mathrm{THD}}(\mathrm{Y} 1)$ & 10.62 & 0.11 & 0.27 & 0.22 & 0.23 \\
\hline $\mathrm{V}_{\mathrm{THD}}(\mathrm{B} 1)$ & 10.61 & 0.11 & 0.26 & 0.23 & 0.24 \\
\hline $\mathrm{I}_{\mathrm{THD}}(\mathrm{R} 1)$ & 14.75 & 0.66 & 0.89 & 1.93 & 1.43 \\
\hline $\mathrm{I}_{\mathrm{THD}}(\mathrm{Y} 1)$ & 14.52 & 0.65 & 0.88 & 1.86 & 1.40 \\
\hline $\mathrm{I}_{\mathrm{THD}}(\mathrm{B} 1)$ & 14.72 & 0.64 & 0.92 & 1.90 & 1.47 \\
\hline $\mathrm{V}_{\mathrm{THD}}(\mathrm{R} 2)$ & 64.31 & 0.60 & 1.44 & 1.35 & 1.28 \\
\hline $\mathrm{V}_{\mathrm{THD}}(\mathrm{Y} 2)$ & 63.34 & 0.60 & 1.44 & 1.22 & 1.25 \\
\hline $\mathrm{V}_{\mathrm{THD}}(\mathrm{B} 2)$ & 63.55 & 0.59 & 1.43 & 1.27 & 1.29 \\
\hline $\mathrm{I}_{\mathrm{THD}}(\mathrm{R} 2)$ & 14.75 & 0.66 & 0.89 & 1.93 & 1.43 \\
\hline $\mathrm{I}_{\mathrm{THD}}(\mathrm{Y} 2)$ & 14.52 & 0.65 & 0.88 & 1.86 & 1.40 \\
\hline $\mathrm{I}_{\mathrm{THD}}(\mathrm{B} 2)$ & 14.72 & 0.64 & 0.92 & 1.90 & 1.47 \\
\hline
\end{tabular}

Table 7. Analysis of \%Interharmonics in Distribution System during Prefault - Source Voltage at Bus 1

\begin{tabular}{|c|c|c|c|c|c|c|c|c|c|c|c|c|c|c|c|}
\hline \multirow[t]{2}{*}{$\begin{array}{l}\text { Frequency } \\
\text { in } \mathrm{Hz}\end{array}$} & \multicolumn{3}{|c|}{ Without UPQC } & \multicolumn{3}{|c|}{$\begin{array}{l}\text { PI based } \\
\text { conventional } \\
\text { UPQC }\end{array}$} & \multicolumn{3}{|c|}{$\begin{array}{l}\text { FUZZY based } \\
\text { conventional } \\
\text { UPQC }\end{array}$} & \multicolumn{3}{|c|}{$\begin{array}{l}\text { PI based Dual } \\
\text { UPQC }\end{array}$} & \multicolumn{3}{|c|}{$\begin{array}{l}\text { FUZZY based } \\
\text { Dual UPQC }\end{array}$} \\
\hline & $\mathrm{R}$ & $\mathrm{Y}$ & $\mathrm{B}$ & $\mathrm{R}$ & $\mathrm{Y}$ & $\mathrm{B}$ & $\mathrm{R}$ & $\mathrm{Y}$ & $\mathrm{B}$ & $\mathrm{R}$ & $\mathrm{Y}$ & B & $\mathrm{R}$ & $\mathrm{Y}$ & $\mathrm{B}$ \\
\hline 75 & $\begin{array}{l}0.2 \\
9\end{array}$ & $\begin{array}{l}0.3 \\
9\end{array}$ & $\begin{array}{l}0.6 \\
7\end{array}$ & $\begin{array}{l}0.0 \\
6\end{array}$ & $\begin{array}{l}0.0 \\
8\end{array}$ & $\begin{array}{l}0.1 \\
3\end{array}$ & $\begin{array}{l}0.0 \\
1\end{array}$ & $\begin{array}{l}0.0 \\
2\end{array}$ & $\begin{array}{l}0.0 \\
2\end{array}$ & $\begin{array}{l}0.2 \\
6\end{array}$ & $\begin{array}{l}0.1 \\
7\end{array}$ & 0.22 & $\begin{array}{l}0.0 \\
1\end{array}$ & $\begin{array}{l}0.0 \\
1\end{array}$ & 0.02 \\
\hline 125 & $\begin{array}{l}0.2 \\
8 \\
\end{array}$ & $\begin{array}{l}0.3 \\
2 \\
\end{array}$ & $\begin{array}{l}0.5 \\
6\end{array}$ & $\begin{array}{l}0.1 \\
2\end{array}$ & $\begin{array}{l}0.0 \\
9\end{array}$ & $\begin{array}{l}0.1 \\
7\end{array}$ & $\begin{array}{l}0.0 \\
1\end{array}$ & $\begin{array}{l}0.0 \\
2\end{array}$ & $\begin{array}{l}0.0 \\
2\end{array}$ & $\begin{array}{l}0.1 \\
1\end{array}$ & $\begin{array}{l}0.3 \\
0\end{array}$ & 0.20 & $\begin{array}{l}0.0 \\
1 \\
\end{array}$ & $\begin{array}{l}0.0 \\
1 \\
\end{array}$ & 0.02 \\
\hline 175 & $\begin{array}{l}0.3 \\
3\end{array}$ & $\begin{array}{l}0.2 \\
5\end{array}$ & $\begin{array}{l}0.5 \\
2\end{array}$ & $\begin{array}{l}0.0 \\
5\end{array}$ & $\begin{array}{l}0.1 \\
4\end{array}$ & $\begin{array}{l}0.1 \\
3\end{array}$ & $\begin{array}{l}0.0 \\
1\end{array}$ & $\begin{array}{l}0.0 \\
1\end{array}$ & $\begin{array}{l}0.0 \\
1\end{array}$ & $\begin{array}{l}0.2 \\
3\end{array}$ & $\begin{array}{l}0.2 \\
5\end{array}$ & 0.03 & $\begin{array}{l}0.0 \\
1\end{array}$ & $\begin{array}{l}0.0 \\
1\end{array}$ & 0.01 \\
\hline 225 & $\begin{array}{l}0.3 \\
8\end{array}$ & $\begin{array}{l}0.2 \\
0\end{array}$ & $\begin{array}{l}0.5 \\
3\end{array}$ & $\begin{array}{l}0.0 \\
4\end{array}$ & $\begin{array}{l}0.0 \\
8\end{array}$ & $\begin{array}{l}0.0 \\
5\end{array}$ & $\begin{array}{l}0.0 \\
1\end{array}$ & $\begin{array}{l}0.0 \\
1\end{array}$ & $\begin{array}{l}0.0 \\
1\end{array}$ & $\begin{array}{l}0.0 \\
4\end{array}$ & $\begin{array}{l}0.1 \\
5\end{array}$ & 0.18 & $\begin{array}{l}0.0 \\
2\end{array}$ & $\begin{array}{l}0.0 \\
1\end{array}$ & 0.01 \\
\hline
\end{tabular}




\begin{tabular}{|c|c|c|c|c|c|c|c|c|c|c|c|c|c|c|c|}
\hline 275 & $\begin{array}{l}0.3 \\
9 \\
\end{array}$ & $\begin{array}{l}0.1 \\
7 \\
\end{array}$ & $\begin{array}{l}0.5 \\
3 \\
\end{array}$ & $\begin{array}{l}0.0 \\
8 \\
\end{array}$ & $\begin{array}{l}0.1 \\
3 \\
\end{array}$ & $\begin{array}{l}0.0 \\
9 \\
\end{array}$ & $\begin{array}{l}0.0 \\
1 \\
\end{array}$ & $\begin{array}{l}0.0 \\
1 \\
\end{array}$ & $\begin{array}{l}0.0 \\
1 \\
\end{array}$ & $\begin{array}{l}0.1 \\
9 \\
\end{array}$ & $\begin{array}{l}0.1 \\
3 \\
\end{array}$ & 0.19 & $\begin{array}{l}0.0 \\
2 \\
\end{array}$ & 0.0 & 0.02 \\
\hline 325 & $\begin{array}{l}0.3 \\
7\end{array}$ & $\begin{array}{l}0.1 \\
4\end{array}$ & $\begin{array}{l}0.4 \\
9\end{array}$ & $\begin{array}{l}0.0 \\
7\end{array}$ & $\begin{array}{l}0.0 \\
9\end{array}$ & $\begin{array}{l}0.1 \\
6\end{array}$ & $\begin{array}{l}0.0 \\
1\end{array}$ & 0.0 & $\begin{array}{l}0.0 \\
1\end{array}$ & $\begin{array}{l}0.0 \\
8\end{array}$ & $\begin{array}{l}0.0 \\
2\end{array}$ & 0.06 & $\begin{array}{l}0.0 \\
2\end{array}$ & 0.0 & 0.02 \\
\hline 375 & $\begin{array}{l}0.3 \\
2\end{array}$ & $\begin{array}{l}0.1 \\
1\end{array}$ & $\begin{array}{l}0.4 \\
0\end{array}$ & $\begin{array}{l}0.0 \\
5\end{array}$ & $\begin{array}{l}0.0 \\
8\end{array}$ & $\begin{array}{l}0.1 \\
3\end{array}$ & $\begin{array}{l}0.0 \\
2\end{array}$ & $\begin{array}{l}0.0 \\
1\end{array}$ & $\begin{array}{l}0.0 \\
2\end{array}$ & $\begin{array}{l}0.1 \\
7\end{array}$ & $\begin{array}{l}0.0 \\
9\end{array}$ & 0.13 & $\begin{array}{l}0.0 \\
1\end{array}$ & 0.0 & 0.01 \\
\hline 425 & $\begin{array}{l}0.3 \\
0 \\
\end{array}$ & $\begin{array}{l}0.0 \\
5\end{array}$ & $\begin{array}{l}0.3 \\
3 \\
\end{array}$ & $\begin{array}{l}0.0 \\
3 \\
\end{array}$ & $\begin{array}{l}0.1 \\
1 \\
\end{array}$ & $\begin{array}{l}0.1 \\
1\end{array}$ & $\begin{array}{l}0.0 \\
2\end{array}$ & $\begin{array}{l}0.0 \\
1 \\
\end{array}$ & $\begin{array}{l}0.0 \\
1 \\
\end{array}$ & $\begin{array}{l}0.0 \\
2\end{array}$ & $\begin{array}{l}0.1 \\
8 \\
\end{array}$ & 0.18 & $\begin{array}{l}0.0 \\
1 \\
\end{array}$ & 0.0 & 0.01 \\
\hline
\end{tabular}

Table 8. Analysis of \%Interharmonics in Distribution System during Prefault - Load Voltage at Bus 2

\begin{tabular}{|c|c|c|c|c|c|c|c|c|c|c|c|c|c|c|c|}
\hline \multirow[t]{2}{*}{$\begin{array}{l}\text { Frequency } \\
\text { in } \mathrm{Hz}\end{array}$} & \multicolumn{3}{|c|}{ Without UPQC } & \multicolumn{3}{|c|}{$\begin{array}{l}\text { PI based } \\
\text { conventional } \\
\text { UPQC }\end{array}$} & \multicolumn{3}{|c|}{$\begin{array}{l}\text { FUZZY based } \\
\text { conventional } \\
\text { UPQC }\end{array}$} & \multicolumn{3}{|c|}{$\begin{array}{l}\text { PI based Dual } \\
\text { UPQC }\end{array}$} & \multicolumn{3}{|c|}{$\begin{array}{l}\text { FUZZY based } \\
\text { Dual UPQC }\end{array}$} \\
\hline & $\mathrm{R}$ & $\mathrm{Y}$ & B & $\mathrm{R}$ & $\mathrm{Y}$ & $\mathrm{B}$ & $\mathrm{R}$ & $\mathrm{Y}$ & $\mathrm{B}$ & $\mathrm{R}$ & $\mathrm{Y}$ & B & $\mathrm{R}$ & $\mathrm{Y}$ & B \\
\hline 75 & 1.63 & $\begin{array}{l}2.0 \\
2 \\
\end{array}$ & $\begin{array}{l}3.6 \\
6\end{array}$ & $\begin{array}{l}0.3 \\
7\end{array}$ & $\begin{array}{l}0.4 \\
7\end{array}$ & $\begin{array}{l}0.7 \\
3 \\
\end{array}$ & $\begin{array}{l}0.0 \\
6\end{array}$ & $\begin{array}{l}0.0 \\
8 \\
\end{array}$ & $\begin{array}{l}0.0 \\
8 \\
\end{array}$ & $\begin{array}{l}1.5 \\
0\end{array}$ & $\begin{array}{l}0.9 \\
9\end{array}$ & $\begin{array}{l}1.2 \\
2\end{array}$ & $\begin{array}{l}0.0 \\
6\end{array}$ & $\begin{array}{l}0.0 \\
8\end{array}$ & 0.09 \\
\hline 125 & 1.65 & $\begin{array}{l}1.6 \\
6\end{array}$ & $\begin{array}{l}3.1 \\
0\end{array}$ & $\begin{array}{l}0.7 \\
1\end{array}$ & $\begin{array}{l}0.4 \\
5\end{array}$ & $\begin{array}{l}0.8 \\
8\end{array}$ & $\begin{array}{l}0.0 \\
7\end{array}$ & $\begin{array}{l}0.0 \\
9\end{array}$ & $\begin{array}{l}0.0 \\
9\end{array}$ & $\begin{array}{l}0.6 \\
7\end{array}$ & $\begin{array}{l}1.7 \\
4\end{array}$ & $\begin{array}{l}1.2 \\
1\end{array}$ & $\begin{array}{l}0.0 \\
8\end{array}$ & $\begin{array}{l}0.0 \\
8\end{array}$ & 0.09 \\
\hline 175 & 1.96 & $\begin{array}{l}1.2 \\
4\end{array}$ & $\begin{array}{l}2.9 \\
1\end{array}$ & $\begin{array}{l}0.2 \\
7\end{array}$ & $\begin{array}{l}0.7 \\
5\end{array}$ & $\begin{array}{l}0.6 \\
8\end{array}$ & $\begin{array}{l}0.0 \\
6\end{array}$ & $\begin{array}{l}0.0 \\
8\end{array}$ & $\begin{array}{l}0.0 \\
7\end{array}$ & $\begin{array}{l}1.3 \\
1\end{array}$ & $\begin{array}{l}1.4 \\
4\end{array}$ & $\begin{array}{l}0.2 \\
1\end{array}$ & $\begin{array}{l}0.0 \\
7\end{array}$ & $\begin{array}{l}0.0 \\
6\end{array}$ & 0.06 \\
\hline 225 & 2.24 & $\begin{array}{l}0.9 \\
9\end{array}$ & $\begin{array}{l}3.0 \\
4\end{array}$ & $\begin{array}{l}0.2 \\
2\end{array}$ & $\begin{array}{l}0.4 \\
2\end{array}$ & $\begin{array}{l}0.2 \\
2\end{array}$ & $\begin{array}{l}0.0 \\
6\end{array}$ & $\begin{array}{l}0.0 \\
7\end{array}$ & $\begin{array}{l}0.0 \\
4\end{array}$ & $\begin{array}{l}0.2 \\
5\end{array}$ & $\begin{array}{l}0.8 \\
4\end{array}$ & $\begin{array}{l}1.0 \\
5\end{array}$ & $\begin{array}{l}0.0 \\
9\end{array}$ & $\begin{array}{l}0.0 \\
5\end{array}$ & 0.06 \\
\hline 275 & 2.29 & $\begin{array}{l}0.8 \\
4\end{array}$ & $\begin{array}{l}3.0 \\
4\end{array}$ & $\begin{array}{l}0.4 \\
4\end{array}$ & $\begin{array}{l}0.7 \\
3\end{array}$ & $\begin{array}{l}0.5 \\
5\end{array}$ & $\begin{array}{l}0.0 \\
7\end{array}$ & $\begin{array}{l}0.0 \\
4\end{array}$ & $\begin{array}{l}0.0 \\
4\end{array}$ & $\begin{array}{l}1.0 \\
5\end{array}$ & $\begin{array}{l}0.7 \\
7\end{array}$ & $\begin{array}{l}1.0 \\
7\end{array}$ & $\begin{array}{l}0.1 \\
1\end{array}$ & $\begin{array}{l}0.0 \\
2\end{array}$ & 0.09 \\
\hline 325 & 2.11 & $\begin{array}{l}0.7 \\
2\end{array}$ & $\begin{array}{l}2.7 \\
7\end{array}$ & $\begin{array}{l}0.3 \\
9\end{array}$ & $\begin{array}{l}0.5 \\
2\end{array}$ & $\begin{array}{l}0.9 \\
1\end{array}$ & $\begin{array}{l}0.0 \\
8\end{array}$ & $\begin{array}{l}0.0 \\
2\end{array}$ & $\begin{array}{l}0.0 \\
7\end{array}$ & $\begin{array}{l}0.4 \\
5\end{array}$ & $\begin{array}{l}0.1 \\
1\end{array}$ & $\begin{array}{l}0.3 \\
6\end{array}$ & $\begin{array}{l}0.1 \\
0\end{array}$ & $\begin{array}{l}0.0 \\
3\end{array}$ & 0.09 \\
\hline 375 & 1.83 & $\begin{array}{l}0.5 \\
3\end{array}$ & $\begin{array}{l}2.2 \\
6\end{array}$ & $\begin{array}{l}0.2 \\
6\end{array}$ & $\begin{array}{l}0.4 \\
4\end{array}$ & $\begin{array}{l}0.7 \\
1\end{array}$ & $\begin{array}{l}0.1 \\
0\end{array}$ & $\begin{array}{l}0.0 \\
4\end{array}$ & $\begin{array}{l}0.1 \\
0\end{array}$ & $\begin{array}{l}0.9 \\
8\end{array}$ & $\begin{array}{l}0.5 \\
4\end{array}$ & $\begin{array}{l}0.7 \\
4\end{array}$ & $\begin{array}{l}0.0 \\
8\end{array}$ & $\begin{array}{l}0.0 \\
2\end{array}$ & 0.06 \\
\hline 425 & 1.73 & $\begin{array}{l}0.2 \\
0 \\
\end{array}$ & $\begin{array}{l}1.8 \\
7\end{array}$ & $\begin{array}{l}0.1 \\
7 \\
\end{array}$ & $\begin{array}{l}0.5 \\
9\end{array}$ & $\begin{array}{l}0.5 \\
8 \\
\end{array}$ & $\begin{array}{l}0.1 \\
0\end{array}$ & $\begin{array}{l}0.0 \\
4\end{array}$ & $\begin{array}{l}0.0 \\
9\end{array}$ & $\begin{array}{l}0.0 \\
9 \\
\end{array}$ & $\begin{array}{l}1.0 \\
3\end{array}$ & $\begin{array}{l}1.0 \\
4\end{array}$ & $\begin{array}{l}0.0 \\
6 \\
\end{array}$ & $\begin{array}{l}0.0 \\
2\end{array}$ & 0.04 \\
\hline
\end{tabular}

Table 9. Analysis of \% Subharmonics in Distribution System during Prefault

\begin{tabular}{|c|c|c|c|c|c|c|c|c|c|c|c|c|c|c|c|}
\hline \multirow[t]{2}{*}{$\begin{array}{l}\text { System } \\
\text { Parameters }\end{array}$} & \multicolumn{3}{|c|}{ Without UPQC } & \multicolumn{3}{|c|}{$\begin{array}{l}\text { PI based } \\
\text { conventional } \\
\text { UPQC }\end{array}$} & \multicolumn{3}{|c|}{$\begin{array}{l}\text { FUZZY based } \\
\text { conventional } \\
\text { UPQC }\end{array}$} & \multicolumn{3}{|c|}{$\begin{array}{l}\text { PI based Dual } \\
\text { UPQC }\end{array}$} & \multicolumn{3}{|c|}{$\begin{array}{l}\text { FUZZY based } \\
\text { Dual UPQC }\end{array}$} \\
\hline & $\mathrm{R}$ & $\mathrm{Y}$ & B & $\mathrm{R}$ & $\mathrm{Y}$ & $\mathrm{B}$ & $\mathrm{R}$ & $\mathrm{Y}$ & $\mathrm{B}$ & $\mathrm{R}$ & $Y$ & B & $\mathrm{R}$ & $\mathrm{Y}$ & B \\
\hline $\begin{array}{l}\text { Source } \\
\text { Voltage }\end{array}$ & $\begin{array}{l}0.3 \\
4\end{array}$ & $\begin{array}{l}0.4 \\
1\end{array}$ & $\begin{array}{l}0.7 \\
5\end{array}$ & $\begin{array}{l}0.0 \\
3\end{array}$ & $\begin{array}{l}0.0 \\
9\end{array}$ & $\begin{array}{l}0.1 \\
2\end{array}$ & 0.0 & $\begin{array}{l}0.0 \\
1\end{array}$ & $\begin{array}{l}0.0 \\
1\end{array}$ & $\begin{array}{l}0.0 \\
7\end{array}$ & $\begin{array}{l}0.0 \\
1\end{array}$ & $\begin{array}{l}0.0 \\
8\end{array}$ & 0.0 & $\begin{array}{l}0.0 \\
1\end{array}$ & 0.01 \\
\hline $\begin{array}{l}\text { Source } \\
\text { current }\end{array}$ & $\begin{array}{l}1.4 \\
4\end{array}$ & $\begin{array}{l}2.6 \\
4\end{array}$ & $\begin{array}{l}4.1 \\
7\end{array}$ & $\begin{array}{l}2.5 \\
4\end{array}$ & $\begin{array}{l}1.8 \\
1\end{array}$ & $\begin{array}{l}2.3 \\
3\end{array}$ & $\begin{array}{l}0.3 \\
2 \\
\end{array}$ & $\begin{array}{l}0.5 \\
6\end{array}$ & $\begin{array}{l}0.3 \\
4\end{array}$ & $\begin{array}{l}2.0 \\
5\end{array}$ & $\begin{array}{l}0.8 \\
6\end{array}$ & $\begin{array}{l}2.9 \\
4\end{array}$ & $\begin{array}{l}0.2 \\
7\end{array}$ & $\begin{array}{l}0.5 \\
7\end{array}$ & 0.41 \\
\hline $\begin{array}{l}\text { Load } \\
\text { Voltage }\end{array}$ & $\begin{array}{l}1.8 \\
5\end{array}$ & $\begin{array}{l}2.1 \\
5\end{array}$ & $\begin{array}{l}4.0 \\
8\end{array}$ & $\begin{array}{l}0.2 \\
6\end{array}$ & $\begin{array}{l}0.6 \\
1\end{array}$ & $\begin{array}{l}0.8 \\
4\end{array}$ & $\begin{array}{l}0.0 \\
3 \\
\end{array}$ & $\begin{array}{l}0.0 \\
5\end{array}$ & $\begin{array}{l}0.0 \\
6\end{array}$ & $\begin{array}{l}0.5 \\
6\end{array}$ & $\begin{array}{l}0.0 \\
7\end{array}$ & $\begin{array}{l}0.6 \\
2\end{array}$ & $\begin{array}{l}0.0 \\
2\end{array}$ & $\begin{array}{l}0.0 \\
5\end{array}$ & 0.06 \\
\hline $\begin{array}{l}\text { Load } \\
\text { Current }\end{array}$ & $\begin{array}{l}1.4 \\
4\end{array}$ & $\begin{array}{l}2.6 \\
4\end{array}$ & $\begin{array}{l}4.1 \\
7\end{array}$ & $\begin{array}{l}2.5 \\
4\end{array}$ & $\begin{array}{l}1.8 \\
1 \\
\end{array}$ & $\begin{array}{l}2.3 \\
3 \\
\end{array}$ & $\begin{array}{l}0.3 \\
2 \\
\end{array}$ & $\begin{array}{l}0.5 \\
6 \\
\end{array}$ & $\begin{array}{l}0.3 \\
4\end{array}$ & $\begin{array}{l}2.0 \\
5\end{array}$ & $\begin{array}{l}0.8 \\
6\end{array}$ & $\begin{array}{l}2.9 \\
4\end{array}$ & $\begin{array}{l}0.2 \\
7\end{array}$ & $\begin{array}{l}0.5 \\
7\end{array}$ & 0.41 \\
\hline
\end{tabular}


Table 10. Performance Analysis of an Induction motor at the time of start

\begin{tabular}{|c|c|c|c|c|c|c|c|c|c|c|c|c|c|c|c|}
\hline \multirow[t]{2}{*}{$\begin{array}{l}\text { System } \\
\text { Parameters }\end{array}$} & \multicolumn{3}{|c|}{ Without UPQC } & \multicolumn{3}{|c|}{$\begin{array}{l}\text { PI based } \\
\text { conventional } \\
\text { UPQC }\end{array}$} & \multicolumn{3}{|c|}{$\begin{array}{l}\text { FUZZY based } \\
\text { conventional } \\
\text { UPQC }\end{array}$} & \multicolumn{3}{|c|}{$\begin{array}{l}\text { PI based Dual } \\
\text { UPQC }\end{array}$} & \multicolumn{3}{|c|}{$\begin{array}{l}\text { FUZZY based } \\
\text { Dual UPQC }\end{array}$} \\
\hline & $\mathrm{R}$ & $\mathrm{Y}$ & $\mathrm{B}$ & $\mathrm{R}$ & $\mathrm{Y}$ & $\mathrm{B}$ & $\mathrm{R}$ & $\mathrm{Y}$ & $\mathrm{B}$ & $\mathrm{R}$ & $\mathrm{Y}$ & B & $\mathrm{R}$ & $\mathrm{Y}$ & B \\
\hline $\begin{array}{l}\text { Source } \\
\text { Voltage } \\
\text { (V) }\end{array}$ & $\begin{array}{l}40 \\
7.4\end{array}$ & $\begin{array}{l}407 . \\
2\end{array}$ & 407 & $\begin{array}{l}41 \\
4\end{array}$ & $\begin{array}{l}41 \\
4\end{array}$ & 414 & $\begin{array}{l}41 \\
4.5\end{array}$ & $\begin{array}{l}41 \\
4.5\end{array}$ & $\begin{array}{l}41 \\
4.5\end{array}$ & $\begin{array}{l}41 \\
3.8\end{array}$ & $\begin{array}{l}41 \\
3.8\end{array}$ & $\begin{array}{l}41 \\
3.8\end{array}$ & $\begin{array}{l}414 \\
.5\end{array}$ & $\begin{array}{l}41 \\
4.5\end{array}$ & $\begin{array}{l}414 . \\
5\end{array}$ \\
\hline $\begin{array}{l}\text { Source } \\
\text { current(A) }\end{array}$ & $\begin{array}{l}64 . \\
5\end{array}$ & 80 & $\begin{array}{l}67 . \\
5\end{array}$ & 9.8 & 9.7 & $\begin{array}{l}10 . \\
2\end{array}$ & 9.6 & 9.8 & 10 & 7.4 & 7.6 & 7.8 & 9.6 & 9.9 & 9.9 \\
\hline $\begin{array}{l}\text { Load } \\
\text { Voltage }\end{array}$ & $\begin{array}{l}30 \\
8\end{array}$ & 306 & 306 & $\begin{array}{l}40 \\
4\end{array}$ & $\begin{array}{l}40 \\
9\end{array}$ & 405 & $\begin{array}{l}40 \\
6\end{array}$ & $\begin{array}{l}40 \\
6\end{array}$ & $\begin{array}{l}40 \\
6\end{array}$ & $\begin{array}{l}42 \\
0\end{array}$ & $\begin{array}{l}42 \\
0\end{array}$ & $\begin{array}{l}42 \\
0\end{array}$ & 406 & $\begin{array}{l}40 \\
6\end{array}$ & 406 \\
\hline $\begin{array}{l}\text { Load } \\
\text { Current }\end{array}$ & $\begin{array}{l}64 . \\
5\end{array}$ & 80 & $\begin{array}{l}67 . \\
5\end{array}$ & 9 & 9.8 & 10 & 9.6 & 9.8 & 10 & 7 & 7 & 7 & 9.6 & 9.8 & 10 \\
\hline
\end{tabular}
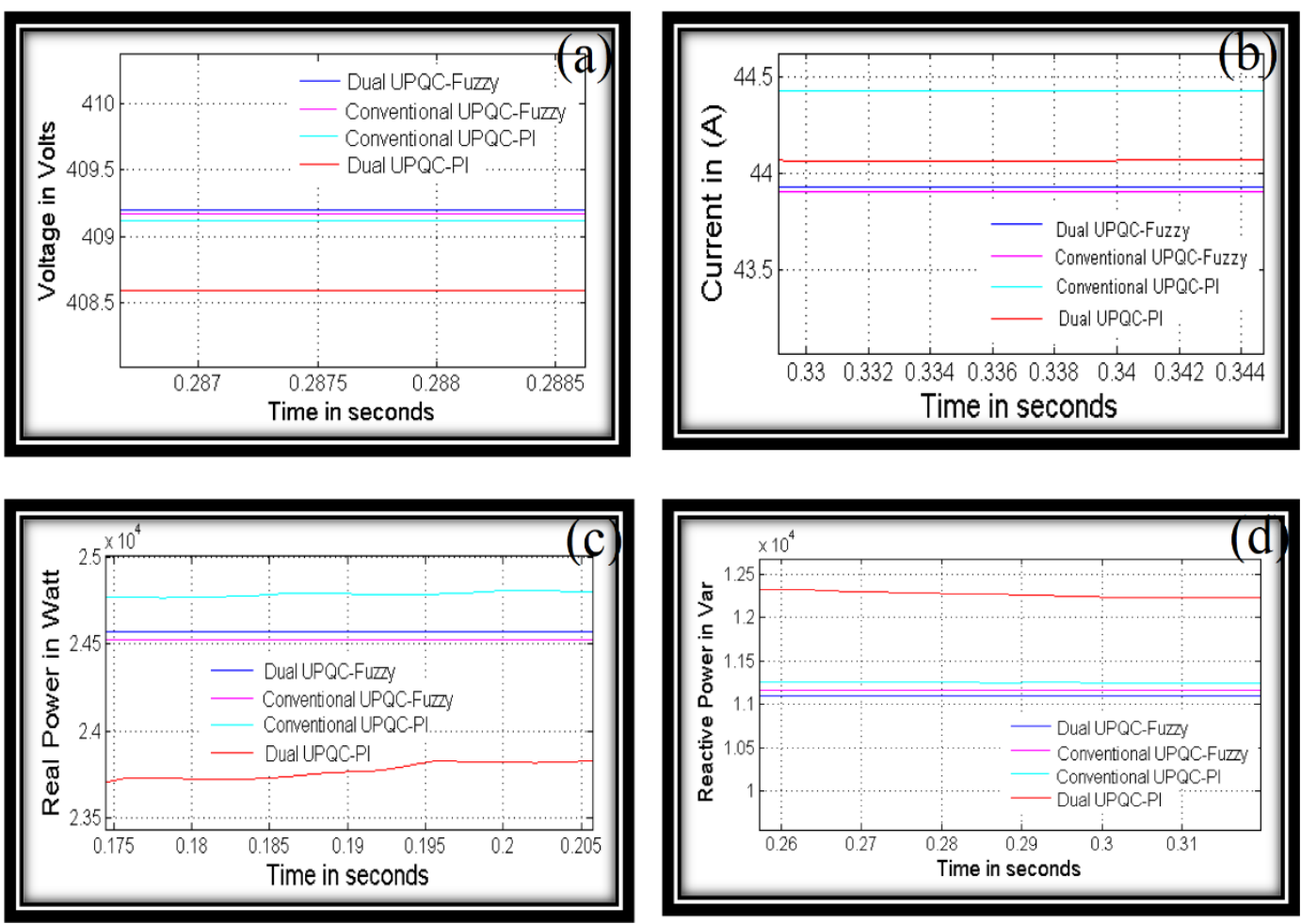

Figure 7. a) Source Voltage b)Source Current, c) Source Real Power d)Source Reactive Power during Single Line to Ground fault at Bus 1 

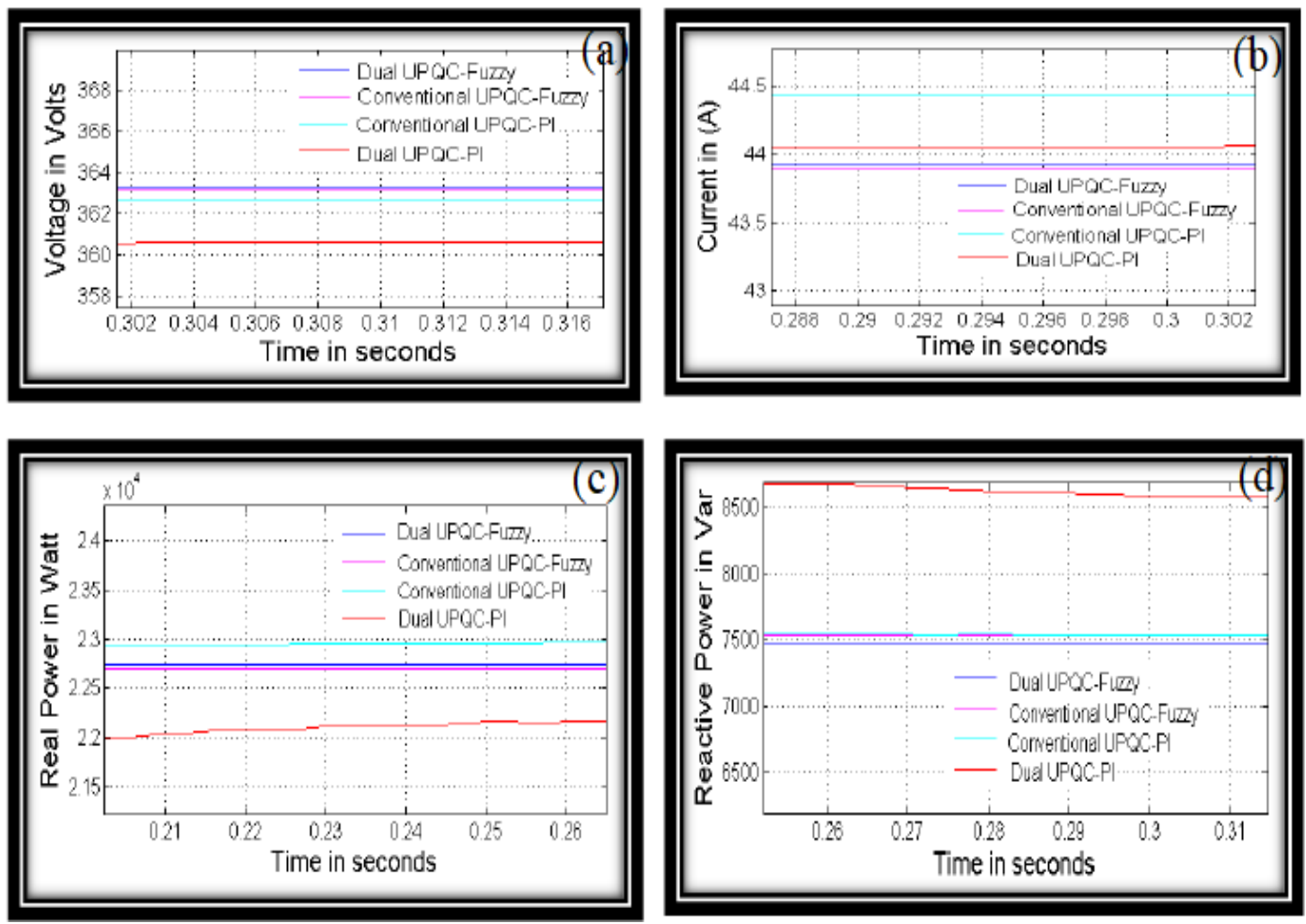

Figure 8. a) Load Voltage b) Load Current, c) Load Real Power d) Load Reactive Power during Single Line to Ground fault at Bus 2
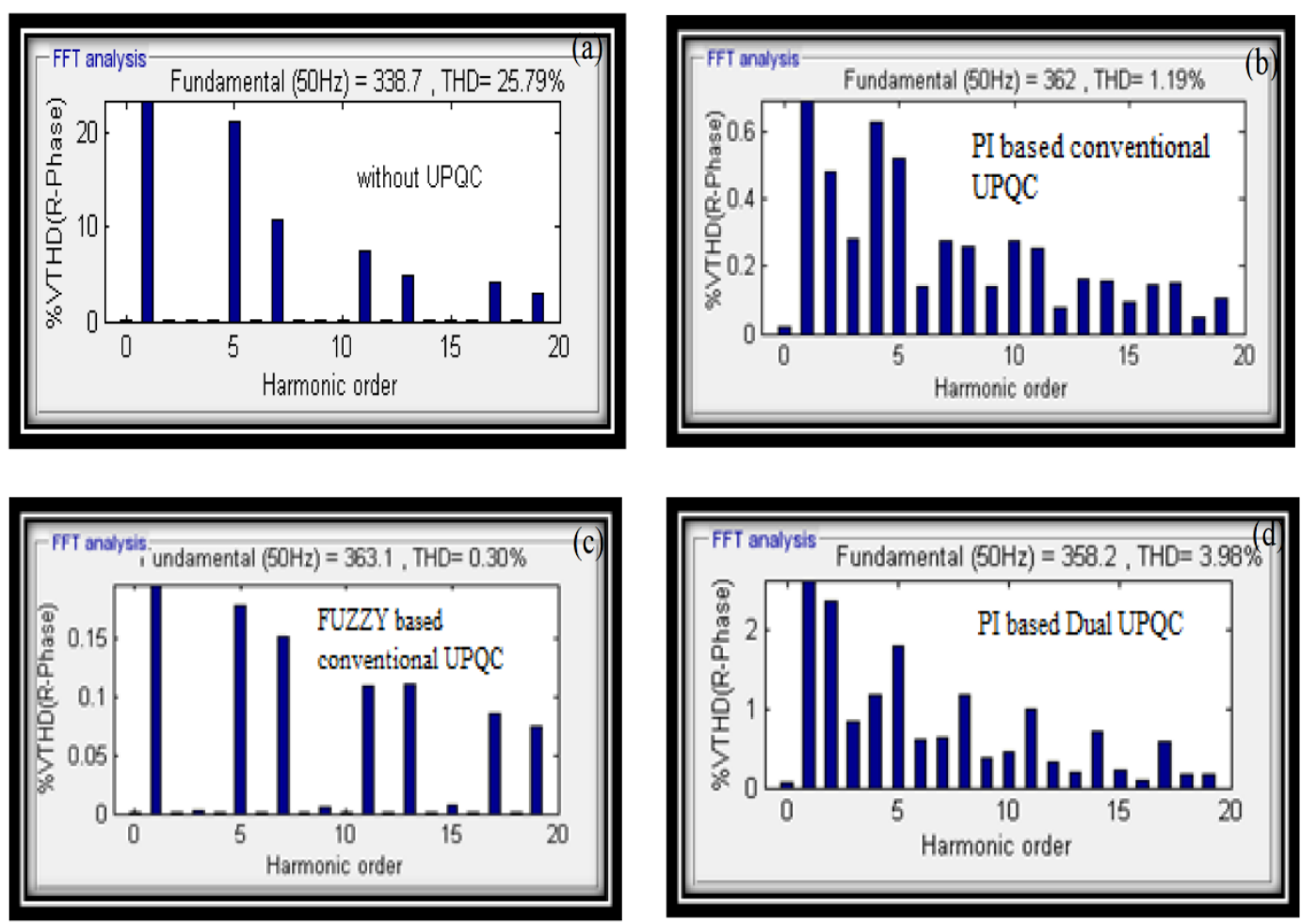


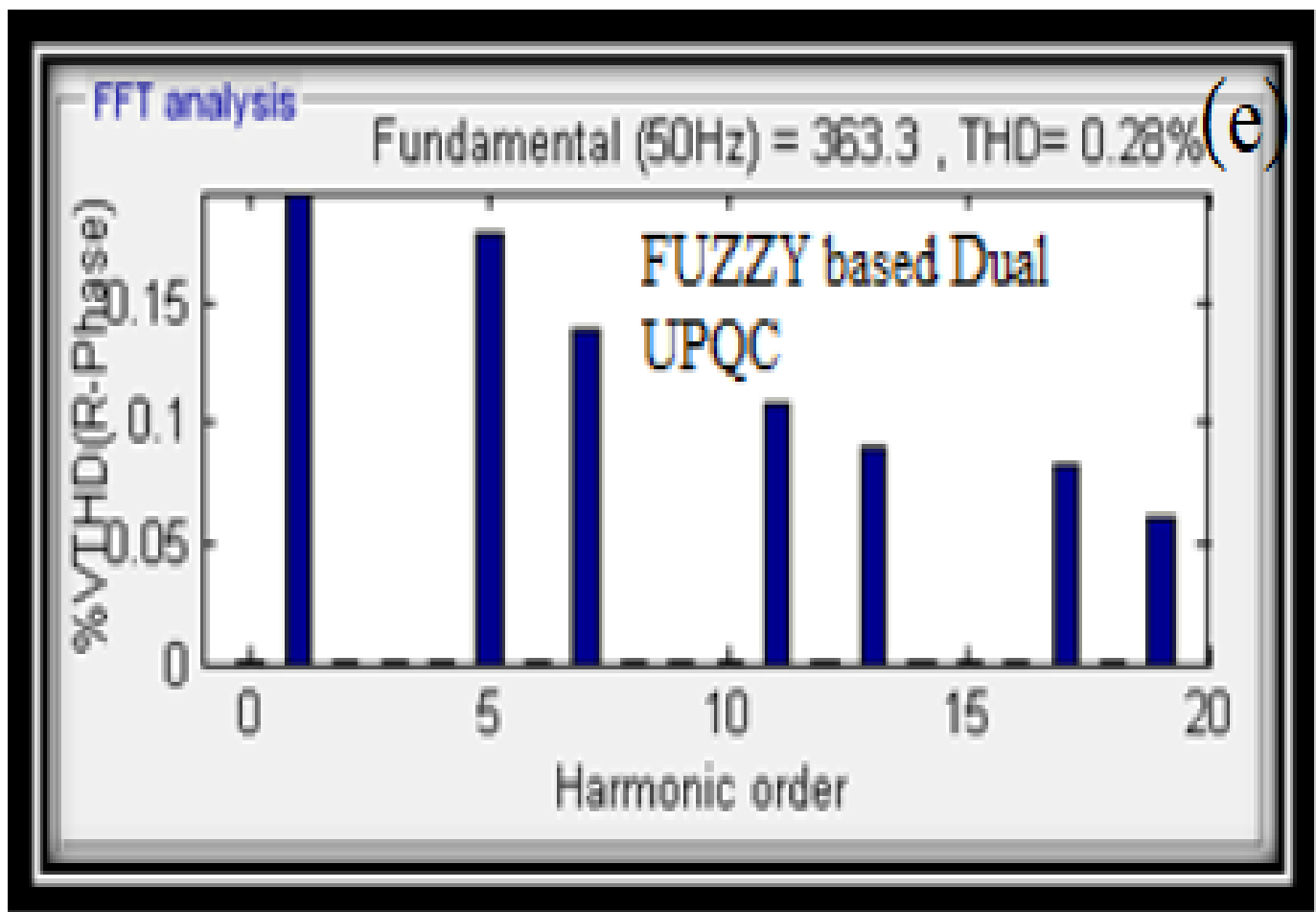

Figure 9(a) to (e). Load Voltage THD measurement in R-phase at Bus 2 under Pre fault condition
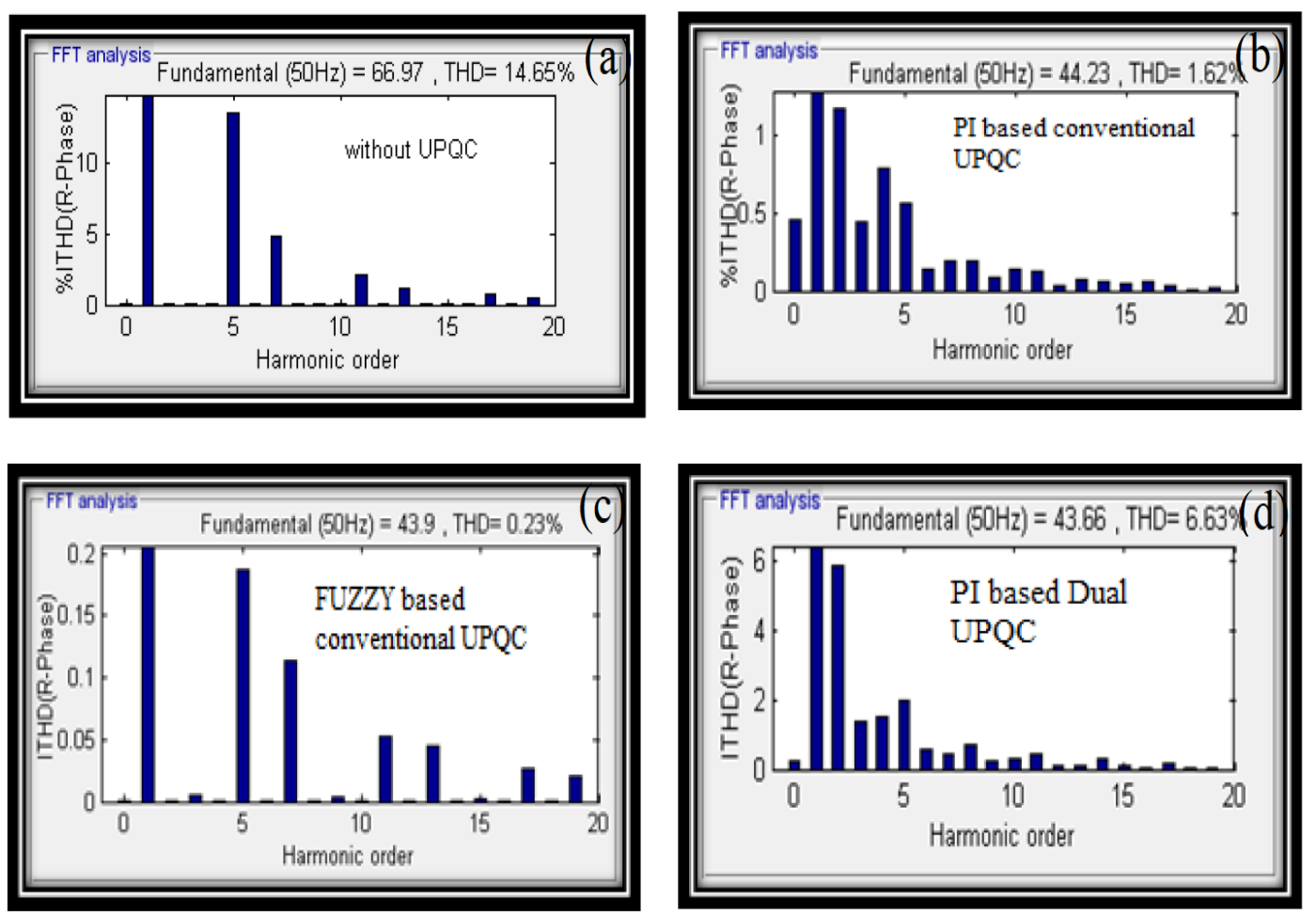


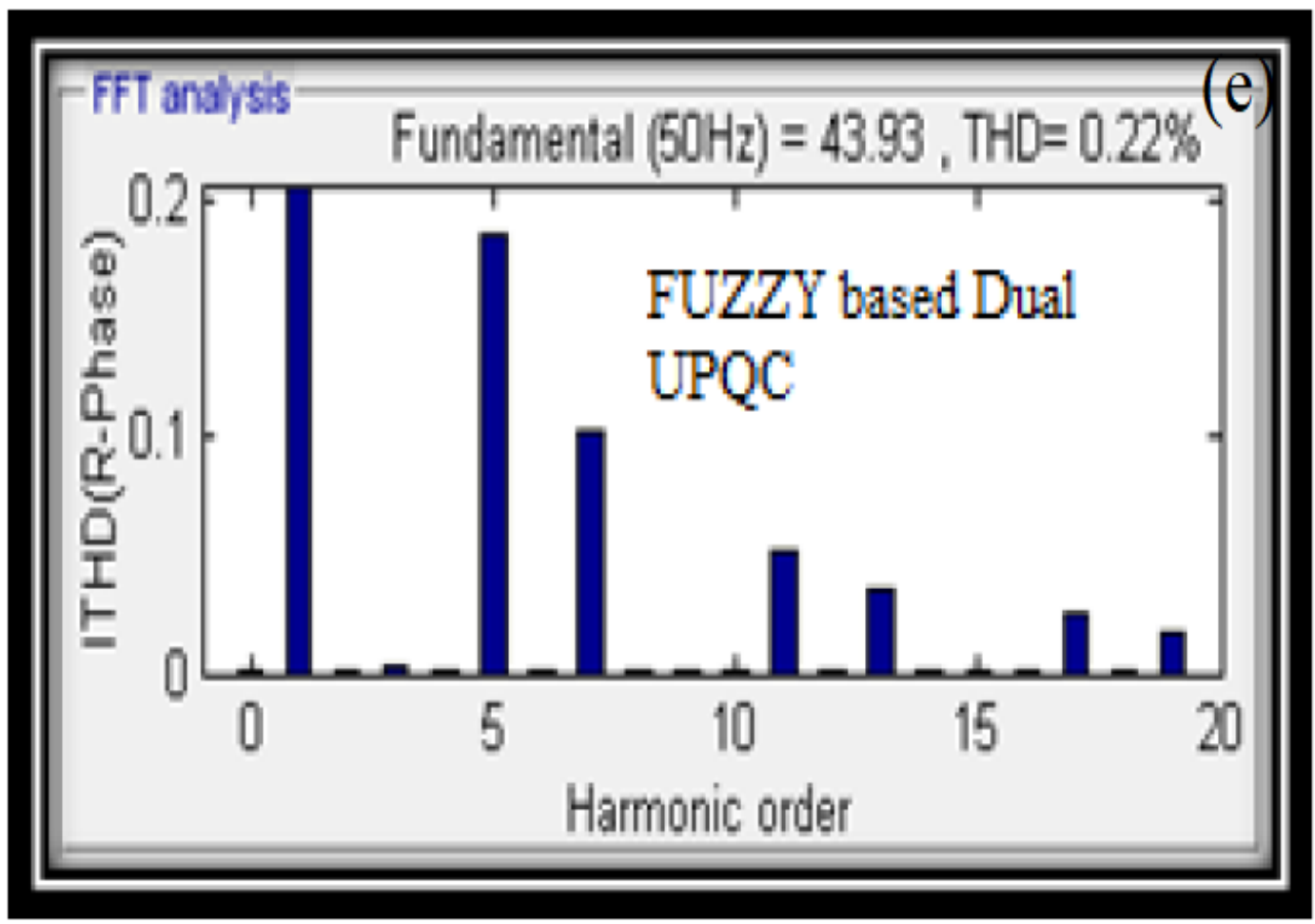

Figure 10(a) to (e). Load Current THD measurement in R-phase at Bus 2 under Pre fault condition

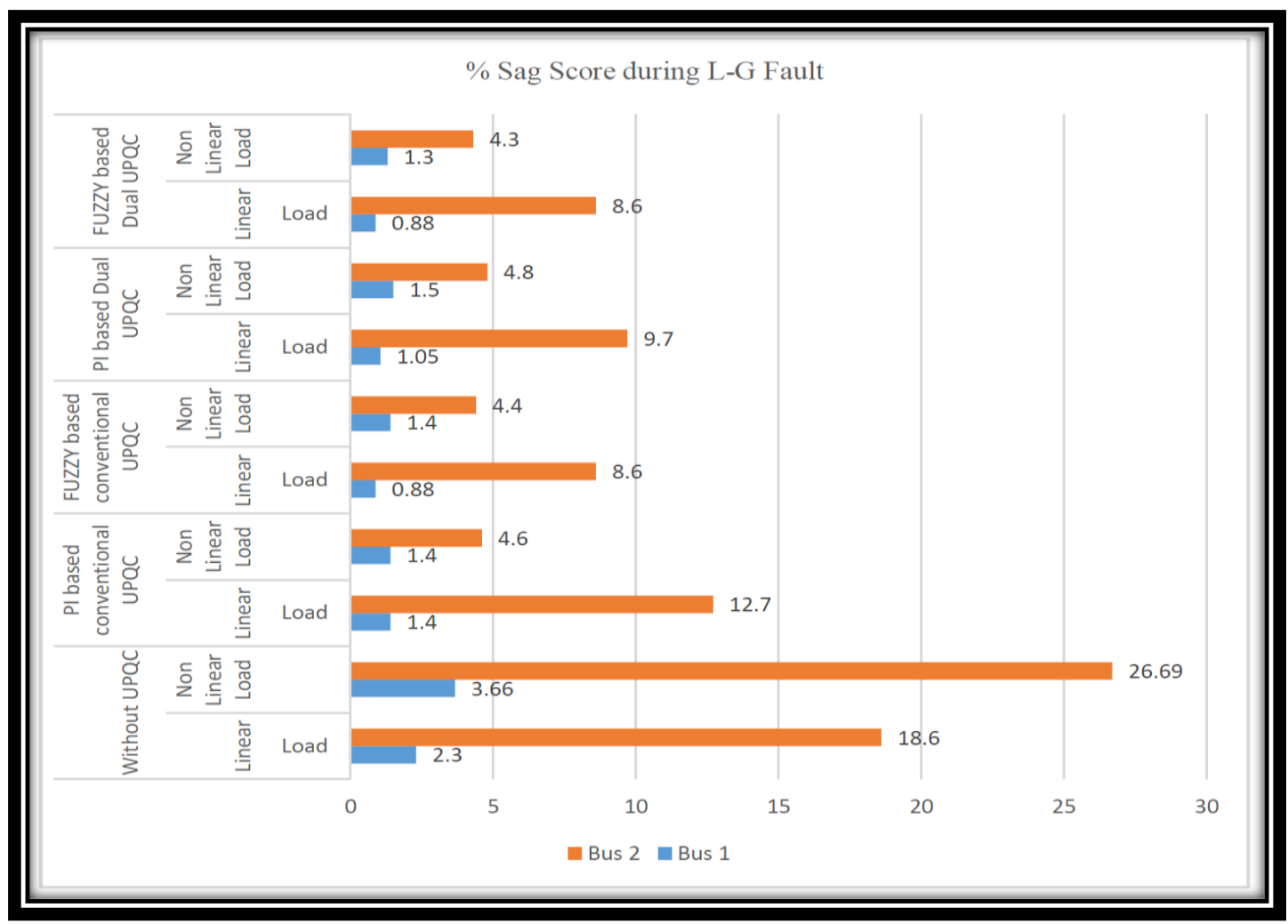

Figure 11. Performance analysis of Sag Score under Line to ground fault 


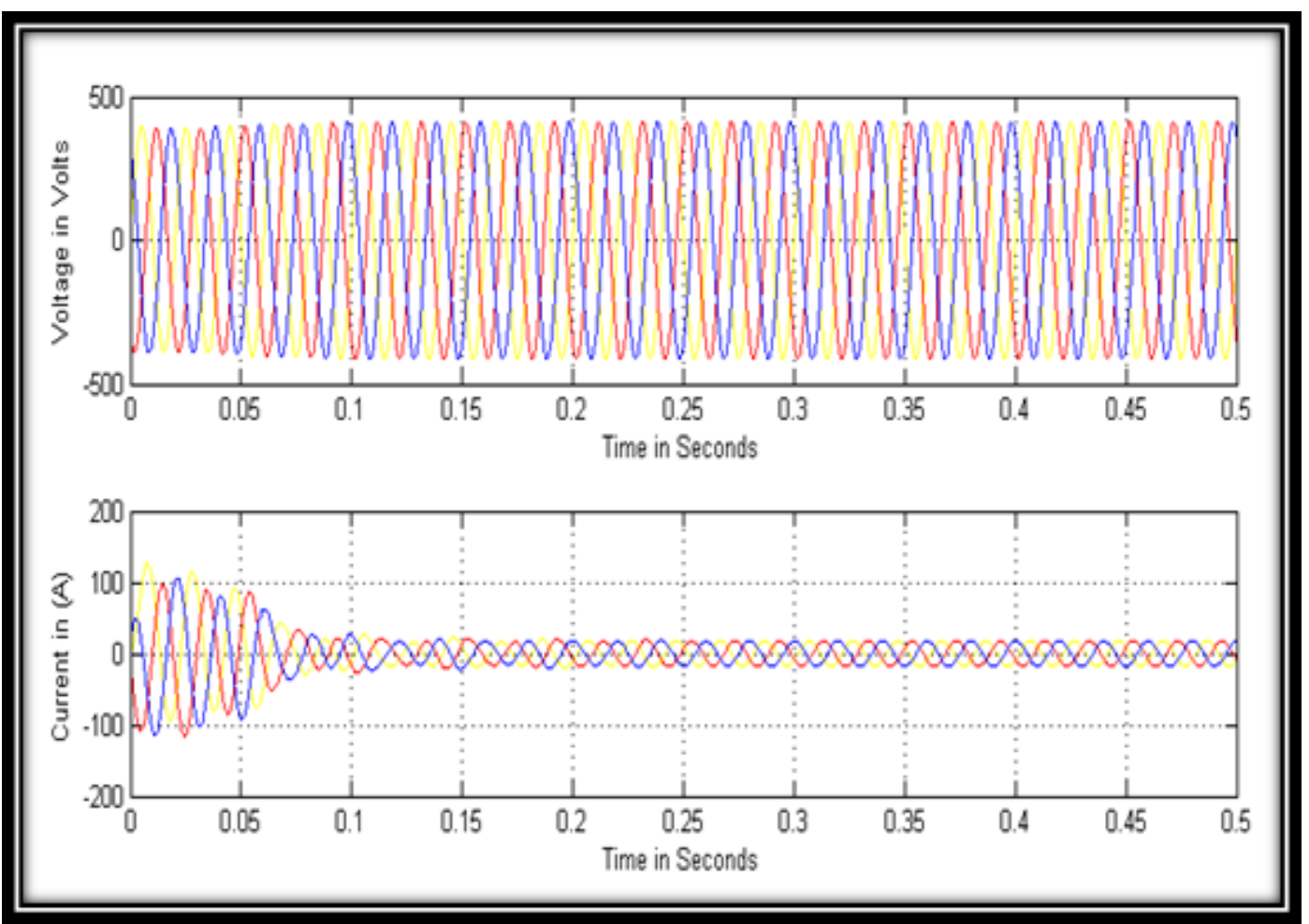

Figure 12. Voltage and Current during starting of Induction motor without UPQC at Bus 1

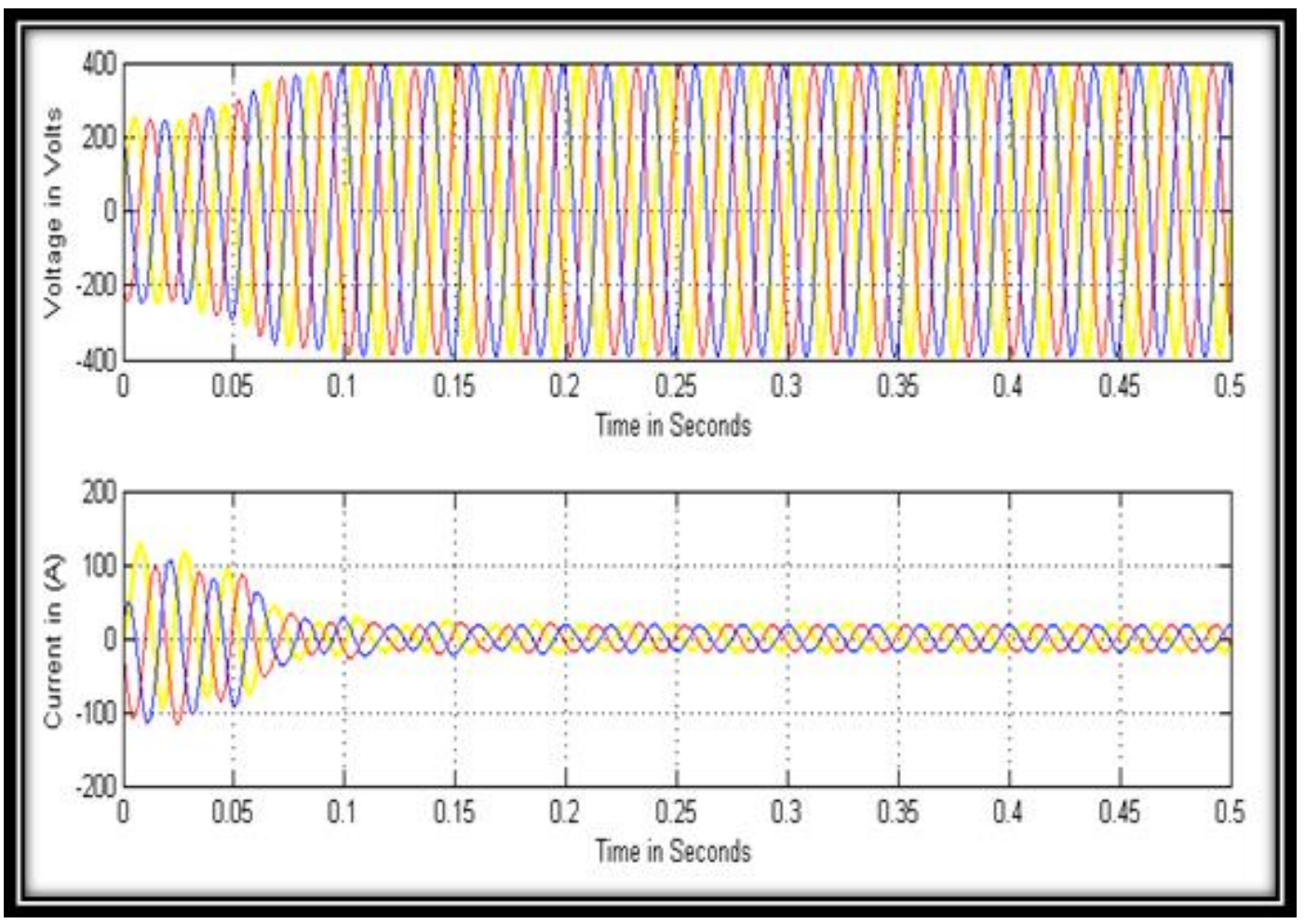

Figure 13. Voltage and Current during starting of Induction motor without UPQC at Bus 2 


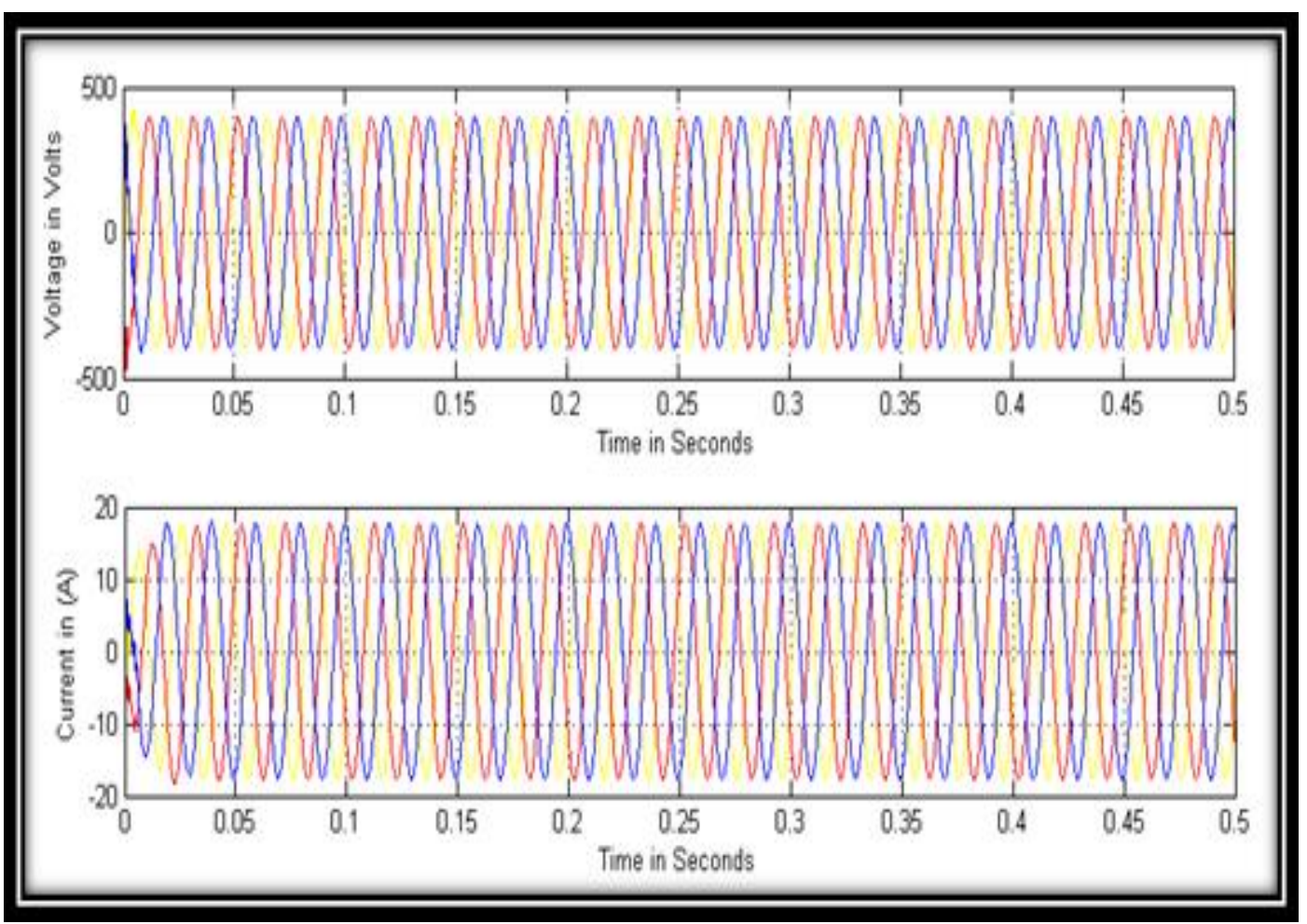

Figure 14. Voltage and Current during starting of Induction motor with Fuzzy based Dual UPQC at BusI

\section{CONCLUSION}

Innovative power electronic devices acting as non linear loads and creates power quality problems in distribution systems. In order to solve the power quality issues, this paper investigates the role of implementing conventional and Dual UPQC in distributions system under unsymmetrical line to ground fault with linear and non linear loads. The closed loop simulation of conventional UPQC and Dual UPQC have been done using SRF based PI controller and Fuzzy controller in the MATLAB SIMULINK environment. The simulation results clearly shows that, Fuzzy based dual UPQC provides better performance in analysing the system parameters such as voltage, current, real power and reactive power and the other power quality issues sag score, THD, Interharmonics, subharmonics and inrush current of induction motor compared to the other three cases such as PI based conventional UPQC, PI based dual UPQC and fuzzy based conventional UPQC. Also the results of subharmonics, THD and interharmonics are met with IEEE and IEC standards. Hence it is suggested that, fuzzy based dual UPQC is the best custom power device for mitigating the power quality issues in distribution system.

\section{CONFLICTS OF INTEREST}

No conflict of interest was declared by authors.

\section{REFERENCES}

[1] Singh, B., Chandra, A., Al-Haddad, K., "Power quality problems and mitigation techniques", 1st ed., John Wiley \& Sons, UK, (2015).

[2] Masoum, M.A.S., Fuchs, E. F., "Power quality in power systems and electrical machines", 2 nd ed., Academic Press, New York, (2015).

[3] Boopathi, C.S., Selvakumar, K. V., Dutta, A., "Enhancing the LVRT capability and mitigation of power quality issues using upqc of a grid connected wind conversion system", Indonesian Journal of Electrical Engineering and Computer Science, 7(3): 643-654, (2017). 
[4] Vinnakoti, S., Kota, V. R., "Performance analysis of ANN-based multilevel UPQC under faulty and overloading conditions", International Journal of Ambient Energy, 1-13, (2019).

[5] Han, B., Bae, B., Kim, H., Baek, S., "Combined operation of unified power-quality conditioner with distributed generation”, IEEE Transaction on Power Delivery, 21(1): 330-338, (2006).

[6] Venkatesh, B., George, M. K., Gooi, H. B., "Fuzzy OPF incorporating UPFC", IEE ProceedingsGeneration, Transmission and Distribution, 151(5): 625-629, ( 2004).

[7] Motamarri, S., Malki, H. A., "Exercise machine controller design", International symposium on Measurement and control in Robotics, USA, 1-7, (2004).

[8] Dixon, J. W., Contardo, J. M., Moran, L. A., "A Fuzzy-controlled active front-end rectifier with current harmonic filtering characteristics and minimum sensing variables", IEEE Transaction on Power Electronics, 14(4): 724-729, (1999).

[9] Jain, S. K., Agarwal, P., Gupta, H. O., "Fuzzy logic controlled shunt active power filter for power quality improvement", IEE Proceedings on Electrical Power Applications, 149(5): 317-328, (2002).

[10] Santos, R. J. M., Cunha, J. C., Mezaroba, M., "A Simplified control technique for a dual unified power quality conditioner", IEEE Transactions On Industrial Electronics, 61(11): 5851-5860, (2014).

[11] Modesto, R. A., Silva, S. A. O., Oliveira, A. A., Bacon, V. D., "A Versatile unified power quality conditioner applied to three-phase four-wire distribution systems using a dual control strategy", IEEE Transactions on Power Electronics, 31(8): 5503-5514, (2016).

[12] Franca, B.W., Silva, L.F., Aredes, M.A., "An improved iUPQC controller to provide additional grid-voltage regulation as a STATCOM", IEEE Transactions on Industrial Electronics, 62(3): 1345-1352, (2015).

[13] Modesto R. A., Silva S. A. O., Oliveira A. A., "Power quality improvement using a dual unified power quality conditioner/uninterruptible power supply in three-phase four-wire systems", IET Power Electronics, 8(3): 1595-1605, (2015).

[14] Silva, S. A. O., Campanhol, L. B. G., Souza, V., "Dynamic performance evaluation of a dual UPQC operating under power quality disturbances", Power conversion and intelligent Motion, Europe, Nuremberg, Germany, 1846-1853, (2018).

[15] Borse, N. S., Shembekar, S. M., "Power quality improvement using dual topology of UPQC", International Conference on Global Trends in Signal Processing, Information Computing and Communication, 428-431, (2016).

[16] Mangayarkarasi S., "Enhancing electric power quality using dual unified power quality conditioner", International Journal of Emerging Technology in Computer Science and Electronics, 12(2): 102-107, (2015).

[17] George, M., “Artificial intelligence based three-phase unified power quality conditioner”, Journal of Computer Science, 3(7): 465-477, (2007).

[18] IEEE Standards Association., "IEEE Std 519-2014 IEEE recommended practice and requirements for harmonic control in electric power systems", IEEE, New York, 4-6, (2014). 
[19] IEEE Interharmonic Task Force., Cigre 36.05/CIRED 2 CC02 Voltage Quality Working Group., "Interharmonics in power systems", Draft, (1997).

[20] Marz, M. B., Mar. 29, Understanding Power System Interharmonics, (2017).

[21] Internet: Power Standards Lab, Online.https://www.powerstandards.com/tutorials/ieee-powerquality-standards/, (2000).

[22] Das, J.C., "Power system analysis: short-circuit load flow and harmonics", 1 st ed., CRC press, New York, (2002).

[23] Wang, Y., "Comparison of Chinese and international harmonic, interharmonic and flicker standards", MS Thesis, Auburn University, Alabama, 16-18, (2014).

[24] Rashid, M. H., "Power electronics handbook: devices, circuits and applications", 2 nd ed., Elsevier Science, UK, (2010).

[25] Wadhwa, C. L., "Electric power systems", 7 th ed., New Age International, New Delhi, India, (2005)

[26] Thallam, R. S., Heydt, G. T., "Power acceptability and voltage sag indices in the three phase sense", Panel Session on Power Quality - Voltage Sag Indices, IEEE Power Engineering Society Summer Meeting, Seattle, 905-910, (2000).

[27] Ghost, A., Ledwich, G., "Power quality enhancement using custom power devices", 1 st ed., Kluwer Academic, Londan, (2002).

[28] Bollen, M. H. J., "Understanding power quality problems voltage sags and interruptions", 1 st ed., John Wiley \& Sons, New York, (1999).

[29] Bollen, M.H.J., Sabin, D.D., Thallam R.S., "Voltage-sag indices - recent developments in IEEE P1564 Task Force" Symposium on CIGRE/IEEE-PES on Quality and Security of Electric Power Delivery Systems, Montreal, 34-41, (2003).

[30] Caramia, P., Carpinelli, G., Verde, P., "Power quality indices in liberalized markets", 1 st ed., John Wiley \& Sons, UK, (2009). 